\section{Pacific Northwest} National Laboratory

Operated by Battelle for the

U.S. Deparment of Energy

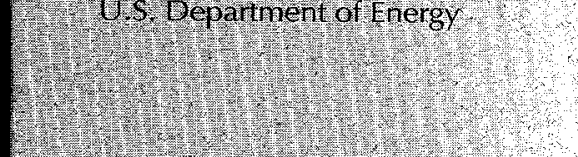<smiles>O=S1(=O)C=CC2=C1C=C2</smiles>

\title{
An Overview of Stationary Fuel Cell Technology
}

\author{
D. R. Brown \\ R. Jones
}

February 1999

Prepared for the U.S. Army Forces Command (FORSCOM) under a Related Services Agreement with the U.S. Department of Energy

Contract DE-AC06-76RLO 1830 


\section{DISCLAIMER}

This report was prepared as an account of work sponsored by an agency of the United States Government. Neither the United States Government nor any agency thereof, nor Battelle Memorial Institute, nor any of their employees, makes any warranty, express or implied, or assumes any legal liability or responsibility for the accuracy, completeness, or usefulness of any information, apparatus, product, or process disclosed, or represents that its use would not infringe privately owned rights. Reference herein to any specific commercial product, process, or service by trade name, trademark, manufacturer, or otherwise does not necessarily constitute or imply its endorsement, recommendation, or favoring by the United States Government or any agency thereof, or Battelle Memorial Institute. The views and opinions of authors expressed herein do not necessarily state or reflect those of the United States Government or any agency thereof.

\section{PACIFIC NORTHWEST NATIONAL LABORATORY operated by BATTELLE MEMORIAL INSTITUTE for the UNITED STATES DEPARTMENT OF ENERGY under Contract DE-ACO6-76RLO 1830}

Printed in the United States of America

Available to DOE and DOE contractors from the

Office of Scientific and Technical Information, P.O. Box 62, Oak Ridge, TN 37831; prices available from (615) 576-8401.

Available to the public from the National Technical Information Service, U.S. Department of Commerce, 5285 Port Royal Rd, Springfield, VA 22161 


\section{DISCLAIMER}

Portions of this document may be illegible in electronic image products. Images are produced from the best available original document. 
PNNL-12147

\title{
An Overview of Stationary Fuel Cell Technology
}

\author{
D.R. Brown \\ R. Jones
}

February 1999

Prepared for the U.S. Army Forces Command (FORSCOM)

Under a Related Services Agreement with the

U.S. Department of Energy

Office of the Federal Energy Management Program

Under Contract MIPR7BR9751013

Pacific Northwest National Laboratory

Richland, WA 99352 


\section{Summary}

Technology developments occurring in the past few years have resulted in the initial commercialization of phosphoric acid (PA) fuel cells. Ongoing research and development (R\&D) promises further improvement in PA fuel cell technology, as well as the development of proton exchange membrane (PEM), molten carbonate (MC), and solid oxide (SO) fuel cell technologies. In the long run, this collection of fuel cell options will be able to serve a wide range of electric power and cogeneration applications.

A fuel cell converts the chemical energy of a fuel into electrical energy without the use of a thermal cycle or rotating equipment. In contrast, most electrical generating devices (e.g., steam and gas turbine cycles, reciprocating engines) first convert chemical energy into thermal energy and then mechanical energy before finally generating electricity. Like a battery, a fuel cell is an electrochemical device, but there are important differences. Batteries store chemical energy and convert it into electrical energy on demand, until the chemical energy has been depleted. Depleted secondary batteries may be recharged by applying an external power source, while depleted primary batteries must be replaced. Fuel cells, on the other hand, will operate continuously, as long as they are externally supplied with a fuel and an oxidant.

Fuel cells have several features that make them attractive candidates for on-site power generation. Electric conversion efficiency is good, ranging around $40 \%$; overall energy efficiency, including the recovery of steam and/or hot water is about $80 \%$. Air emissions are so low that fuel cells have received exemptions from the standard environmental permitting process in several locales, including Southern California, where air emissions regulations are quite restrictive. $\mathrm{NO}_{\mathrm{X}}$ generation is essentially eliminated because the fuel cell is an electrochemical process rather than a high-temperature combustion process. Sulfur or sulfur compounds in the fuel stream can poison catalysts, react with electrolyte, or otherwise reduce cell efficiency (depending on the fuel cell type), so are removed or minimized in the fuel processor. Unlike many power generating technologies, fuel cells do not rely on size economies-of-scale to reduce cost or improve performance. Fuel cells are currently being developed at sub-kW to multi-MW sizes, which covers almost every possible application of interest to an end-user. High reliability has been demonstrated by the PA fuel cells already operating, some with over 40,000 hours of accumulated service. In addition, fuel cells are very quiet and produce clean premium power for servicing sensitive electric loads.

Projected mature product characteristics of the four fuel cells are summarized below. If these projections come true, the hybrid system consisting of a SO oxide fuel cell coupled with a gas turbine will likely become the preferred technology for distributed power generation in the 1- to $10-\mathrm{MW}$ range. Industrial applications requiring high temperature process steam as well as electricity will probably prefer the MC fuel cell. The inherently poorer electrical conversion efficiencies of the PA and PEM fuel cells will likely limit them to commercial or residential applications, although its not clear if PA fuel cells will economically scale down to residential sizes. Economy-of-scale limitations will probably also restrict $\mathrm{MC}$ fuel cells to applications requiring about $250 \mathrm{~kW}$ or more of power generation. Solid oxide fuel cells, on the other hand, are currently being developed in sizes suitable for residential through distributed utility applications. The preference for PA or PEM fuel cells in the commercial market will depend mostly on their relative capital cost, but the PA fuel cell does have the advantage of producing higher temperature cogenerated heat, while the PEM fuel cell has an advantage in weight and volume per unit capacity. 


\section{Projected Mature Fuel Cell Characteristics}

Characteristic
Current Development Status
Initial Commercialization Date
Mature Characteristics Date
Initial Installed Cost, $\$ / \mathrm{kW}$
Cell Stack Replacement Cost, $\$ / \mathrm{kW}$
Cell Stack Life, Operating Hours
Fixed O\&M Cost, $\$ / \mathrm{kW} /$ year
Variable O\&M Cost, $\$ / \mathrm{MWh}$
Electric Efficiency, $\%{ }^{2}$
Cogeneration Efficiency, $\%{ }^{2}$
Cogeneration Temperature, ${ }^{\circ} \mathrm{F}$
Annual Availability, $\%$

\begin{tabular}{|c|c|c|c|}
\hline \multicolumn{4}{|c|}{ Fuel Cell Type } \\
\hline PA & $\underline{\text { PEM }}$ & $\mathrm{MC}$ & $\underline{\mathrm{SO}}$ \\
\hline Commercial & $\mathrm{R} \& \mathrm{D}$ & $\mathrm{R} \& \mathrm{D}$ & $\mathrm{R} \& \mathrm{D}$ \\
\hline 1992 & 2001 & 2002 & 2003 \\
\hline $2005+$ & $2005+$ & $2005+$ & $2005+$ \\
\hline 1500 & 1300 & 1300 & 1300 \\
\hline 360 & 220 & 430 & 400 \\
\hline 60,000 & 40,000 & 50,000 & 40,000 \\
\hline 30 & 30 & 8 & 20 \\
\hline 1.4 & 1.4 & 2.0 & 2.5 \\
\hline 37 & 36 & 52 & 63 \\
\hline 73 & 70 & 82 & 77 \\
\hline 250 & 160 & 1050 & 400 \\
\hline 97 & 96 & 95 & 86 \\
\hline
\end{tabular}

Thirty PA fuel cells sold by ONSI, a subsidiary of United Technologies and Toshiba, have been installed as part of the Department of Defense (DoD) Fuel Cell Demonstration Program. Although none of the 30 was installed at a FORSCOM site, the lessons learned from this program should help determine the role that fuel cells play in the long-term energy supply strategy for FORSCOM, as well as the rest of DoD.

The only significant problem with fuel cells is their high initial cost. The purchase price of an ONSI PA fuel cell (the only fuel cell currently commercially available) is $\$ 3000 / \mathrm{kW}$. While this can be reduced via an ongoing Federal rebate program to $\$ 2000 / \mathrm{kW}$, the cost is still too high to compete with grid-supplied electric power in most locations, even with the cogeneration benefit. Still, if fuel cell technology advances in the next few years match those of the past few years, these costs could be cut in half, resulting in a large number of cost-effective applications. Preliminary economic analyses show that the PA fuel cell could be cost-effective at Ft. Drum and $\mathrm{Ft}$. Irwin now, with the rebate. If projected improvements in the technology are achieved, cost-effectiveness would be extended to include Ft. Bragg and Ft. Polk, without the rebate.

The cost of grid-supplied electric power is the most important site-specific factor affecting fuel cell cost-effectiveness. The cost of fuel and the utilization of waste heat are important, but secondary factors. Deregulation of retail electricity in the next few years will likely reduce the cost of electricity for most electricity users, including FORSCOM. For example, Ft. Drum recently signed an agreement with its electric utility that should reduce its average cost of electricity by about $25 \%$. At a minimum, the prospect of deregulation has created greater uncertainty for future electricity costs, hence greater uncertainty regarding the benefit of any self-generating concept, including fuel cells. Therefore, FORSCOM energy managers should probably wait until the impact of electricity deregulation is clearer before seriously considering

\footnotetext{
${ }^{1}$ Characteristics listed for hybrid power plant with gas turbine bottoming cycle.

${ }^{2}$ The electric and cogeneration efficiencies listed in this table are based on natural gas fuel and its higher heating value.
} 
fuel cells as an energy supply option. Exceptions to this general rule would be applications requiring premium power quality or reliability, or reduced emissions. FORSCOM should also take advantage of any extension in the DoD Fuel Cell Demonstration Program, although there are no plans for an extension at this time. Otherwise, continued monitoring of the progress of fuel cell technology and electricity deregulation would be wise. 



\section{Contents}

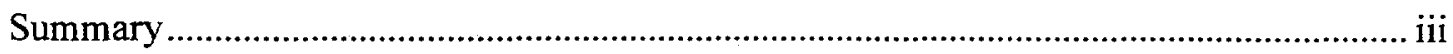

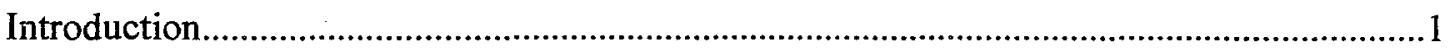

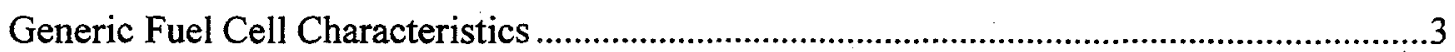

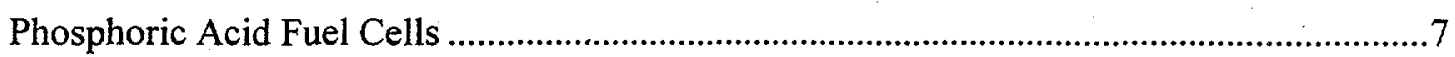

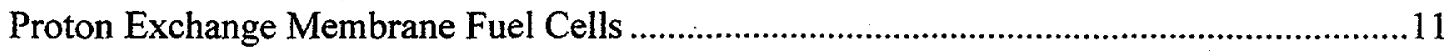

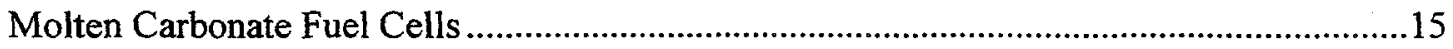

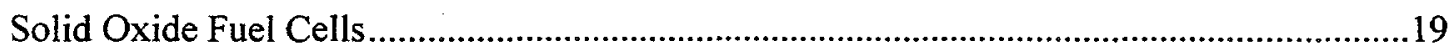

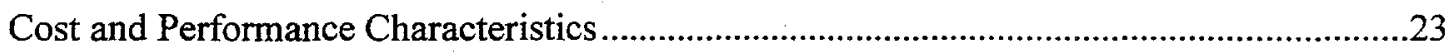

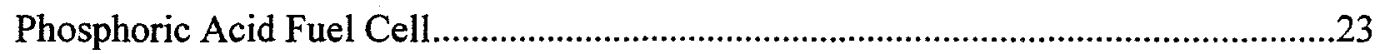

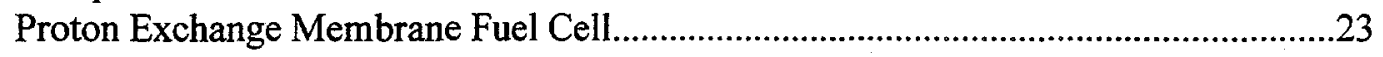

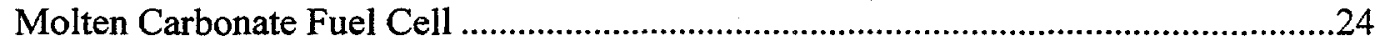

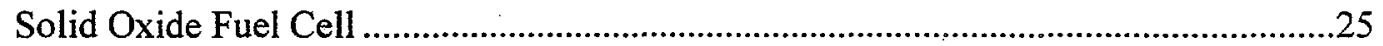

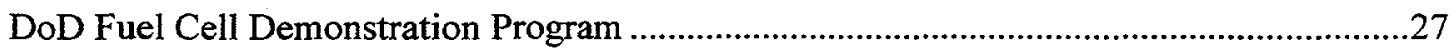

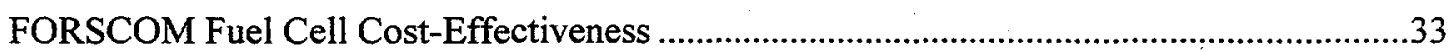

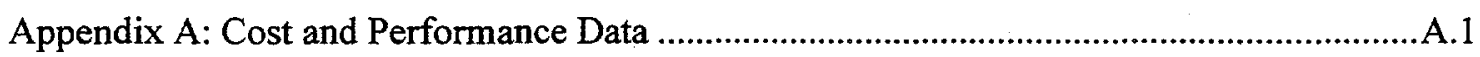

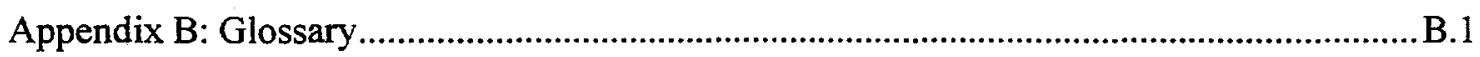




\section{Figures}

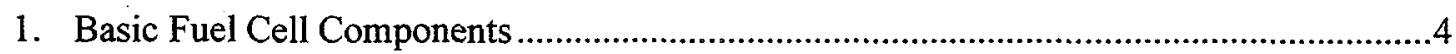

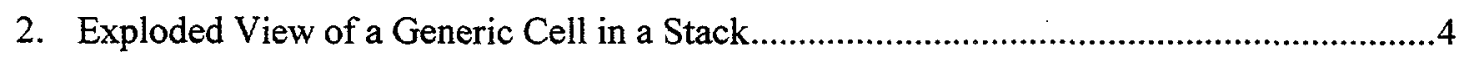

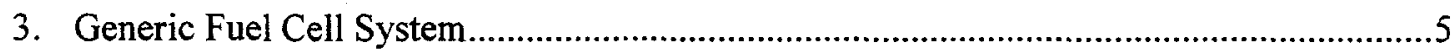

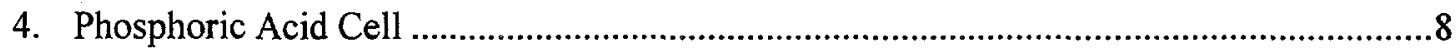

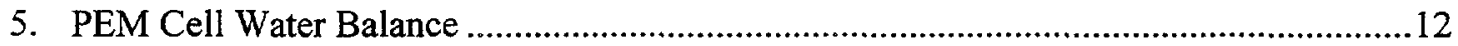

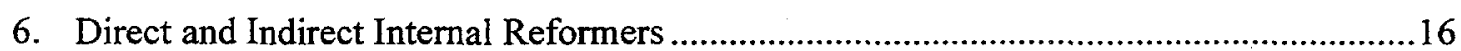

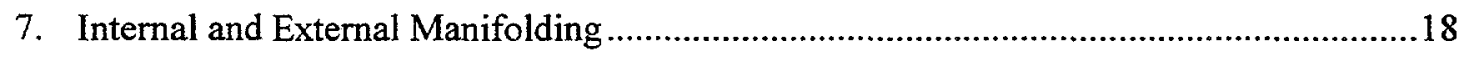

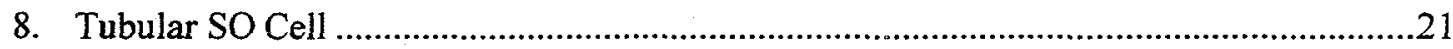

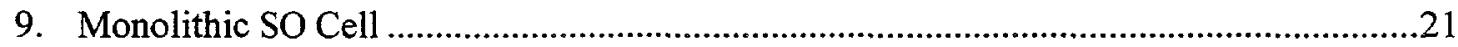

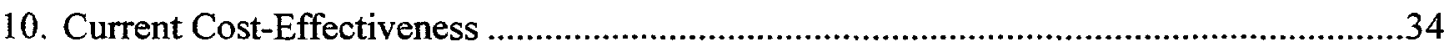

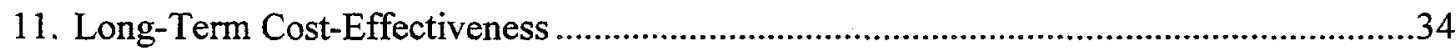




\section{Tables}

Projected Mature Fuel Cell Characteristics ..................................................................... iv

1. DoD Fuel Cell Demonstration Program - Site Contact Data .........................................28

2. DoD Fuel Cell Demonstration Program - Application Data ........................................29

3. DoD Fuel Cell Demonstration Program - Performance Data.........................................31

4. DoD Fuel Cell Demonstration Program - Cost Data........................................................32

5. Economic Assumptions for Cost-Effectiveness Calculations............................................33

A1. Current (1998) Phosphoric Acid Fuel Cell Cost and Performance Characteristics ..........A.2

A2. Long-Term ( 7 to 10 years) Phosphoric Acid Fuel Cell Cost and Performance

Characteristics

A3. Long-Term ( 7 to 10 years) Proton Exchange Membrane Fuel Cell Cost and Performance Characteristics

A4. Long-Term ( 7 to 10 years) Molten Carbonate Fuel Cell Cost and Performance Characteristics

A5. Long-Term (7 to 10 years) Solid Oxide Fuel Cell Cost and Performance CharacteristicsA.6 


\section{Introduction}

This report was prepared by the Pacific Northwest National Laboratory ${ }^{3}$ (PNNL) for the U.S. Army Forces Command (FORSCOM) in Atlanta, Georgia. The report is intended to provide FORSCOM energy managers with information that will help them determine whether fuel cells could be effectively implemented at their facilities now or in the future. In support of this overall objective, the report

- presents an introduction to fuel cell technology

- provides current and projected fuel cell characteristics

- summarizes descriptions of current fuel cell applications

- identifies conditions for cost-effective fuel cell application.

The report generally follows the outline indicated by the bulleted items. The following section describes the characteristics of a generic fuel cell and fuel cell system. The next four sections describe the specific characteristics and developmental status of phosphoric acid (PA), proton exchange membrane (PEM), molten carbonate (MC), and solid oxide (SO) fuel cell systems. Cost and performance characteristics for the four fuel cells are described next, followed by a summary of DoD's Fuel Cell Demonstration Program. Finally, the last section identifies the conditions that would make a fuel cell attractive and relates this to current and projected utility rates at FORSCOM installations. Current and projected cost and performance characteristics are presented in Appendix A, while a glossary of fuel cell terms is presented in Appendix B.

${ }^{3}$ PNNL is operated for the U.S. Department of Energy by Battelle Memorial Institute under Contract DEAC06-76RLO 1830. 


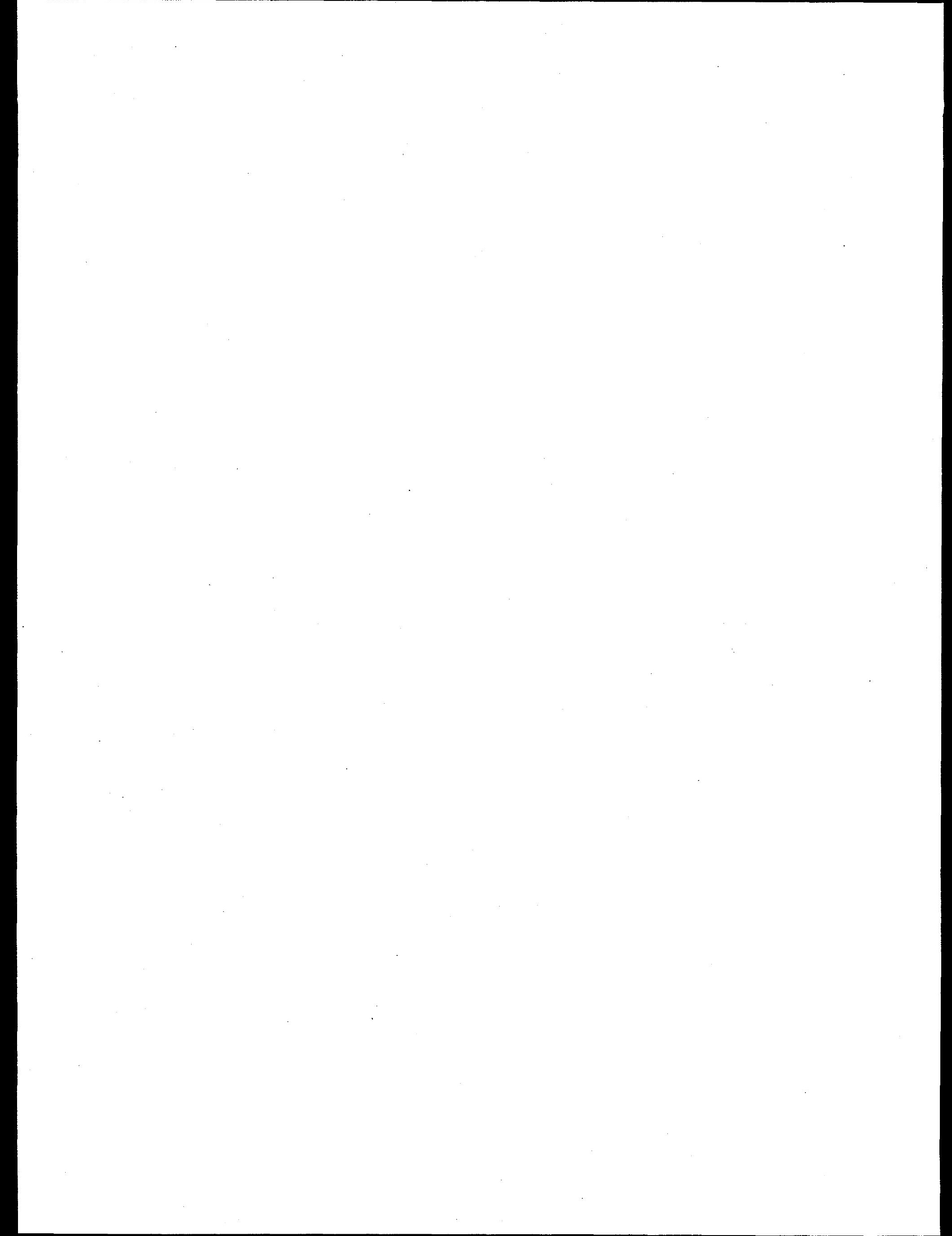




\section{Generic Fuel Cell Characteristics}

A fuel cell converts the chemical energy of a fuel into electrical energy without the use of a thermal cycle or rotating equipment. In contrast, most electrical generating devices (e.g., steam and gas turbine cycles, reciprocating engines) first convert chemical energy into thermal energy and then into mechanical energy before finally generating electricity. Like a battery, a fuel cell is an electrochemical device, but there are important differences. Batteries store chemical energy and convert it into electrical energy on demand, until the chemical energy has been depleted. Depleted secondary batteries may be recharged by applying an external power source, while depleted primary batteries must be replaced. Fuel cells, on the other hand, will operate continuously, as long as they are externally supplied with a fuel and an oxidant.

The basic components of a fuel cell, shown in Figure 1, are an electrolyte, an anode, and a cathode. Fuel and oxidant flow past the anode and cathode, respectively, generating electricity via electrochemical oxidation of the fuel and electrochemical reduction of the oxidant. Ions flow through the electrolyte between the anode and the cathode. Electrons generated at the anode flow through an external load to the cathode, completing the electric circuit.

Hydrogen is the preferred fuel because of its higher reactivity, which minimizes the need for expensive catalysts, and because it allows for reasonably-sized cell stacks. Hydrocarbon fuels can be used, but generally require conversion to hydrogen either prior to entering the fuel cell (for lower-temperature fuel cells) or within the fuel cell (for higher-temperature fuel cells). Oxygen is the preferred oxidant because of its ready availability from the atmosphere.

The electrolyte material is the key distinguishing feature of a fuel cell, and is generally used to describe the fuel cell type, as in phosphoric acid (PA), solid polymer electrolyte (SPE) or proton exchange membrane (PEM), molten carbonate (MC), and solid oxide (SO). In general, the electrolyte should allow resistance-free transport of ions between the anode and cathode, while providing a barrier between fuel and oxidant streams. Electrode materials also vary with the fuel cell type, but the basic requirement is to allow the oxidation and reduction reactions to proceed as quickly as possible by facilitating reaction kinetics and mass transfer. Thus, porous, conductive, and catalytic materials are preferred, although the latter is only important for lower temperature (PEM and PA) fuel cells.

An individual cell only produces about 1 volt, so many cells are linked together in series to form a stack with a more useful voltage. The number of cells in a single stack varies considerably, but is typically greater than 50 . Cell stacks can be grouped into various series and parallel combinations to further tailor voltage, current, and power to the needs of a specific application. An exploded view of a generic multi-cell stack is shown in Figure 2. Key components, besides the anode, electrolyte, and cathode described above, are the anode and cathode current collectors and a separator. The separator provides the electrical series connection between cells and physically separates the fuel for one cell from the oxidant for the adjacent cell. The current collectors conduct electrons from the anode to the separator plate and on to the cathode. The channels in the current collectors also serve as distribution pathways for fuel and oxidant. Often, the two current collectors and the separator are combined into a single unit called a bipolar plate. There is one bipolar plate per cell, but each cell uses one-half of two bipolar plates. 


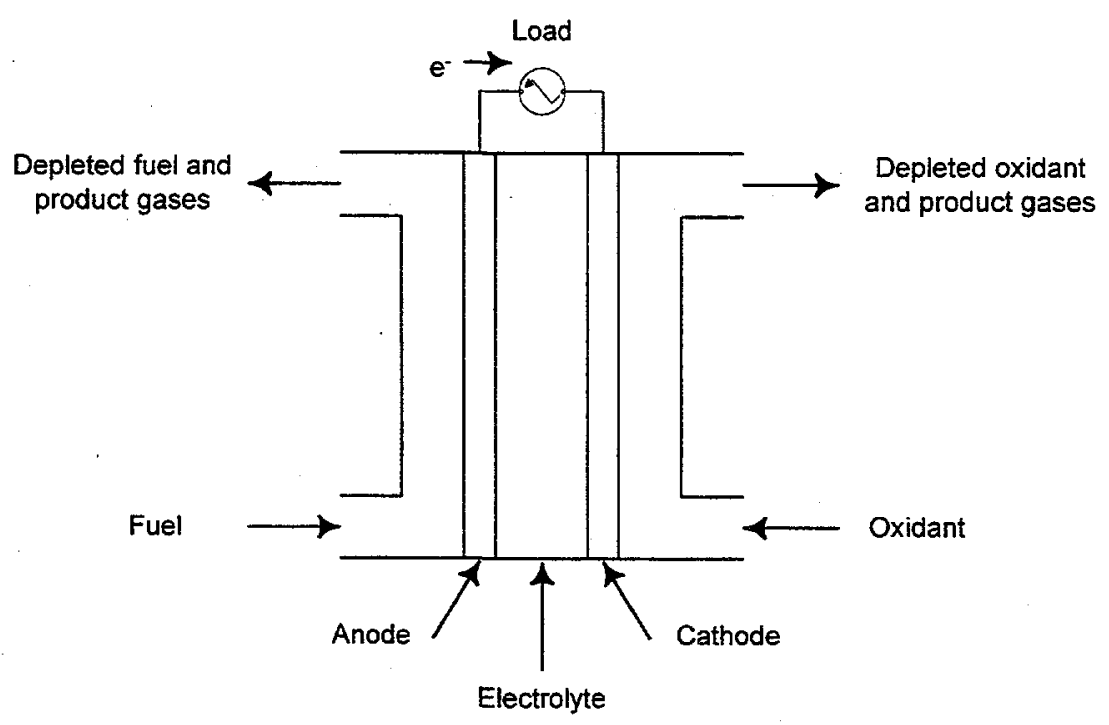

Figure 1. Basic Fuel Cell Components

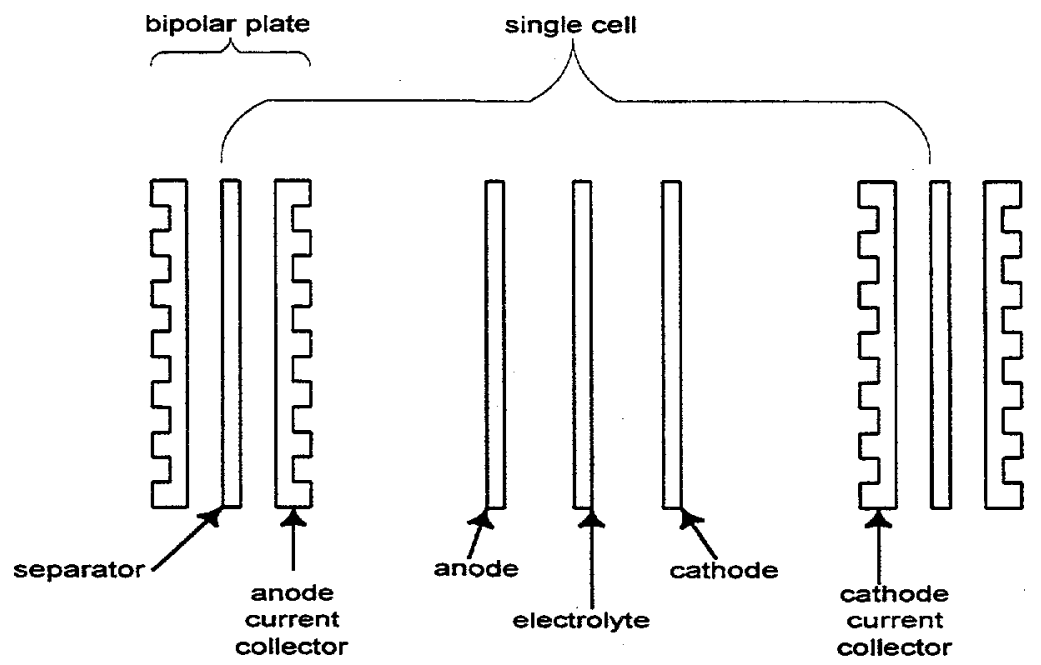

Figure 2. Exploded View of a Generic Cell in Stack

As previously noted, hydrogen is the preferred fuel, especially for fuel cells operating at lower temperatures, where reactions run relatively slowly. Unfortunately, hydrogen is not readily available and is difficult to store. Therefore, a fuel cell system must usually include a fuel processor to convert more readily available or storable fuels, such as natural gas or methanol, into fuel streams that are predominately hydrogen. This is accomplished via one or more chemical processing steps that may include steam reforming, partial oxidation, water-gas-shift, and preferential oxidation reactions.

In steam reforming, hydrocarbon fuels are combined with steam to produce carbon monoxide (CO) and hydrogen. The endothermic steam reforming reaction occurs at high temperature 
(typically 800 to $900^{\circ} \mathrm{C}$ ) and low pressure (usually a few atmospheres). In the exothermic partial oxidation reaction, hydrocarbons and oxygen combine to form $\mathrm{CO}$ and hydrogen rather than the carbon dioxide $\left(\mathrm{CO}_{2}\right)$ and water formed in complete combustion reactions. Reaction temperature and pressure for partial oxidation is similar to that for steam reforming. Partial oxidation produces less hydrogen per unit of fuel than steam reforming, but is more amenable for use with liquid hydrocarbons such as gasoline, diesel, and fuel oil.

Carbon monoxide resulting from either steam reforming or partial oxidation reactions is converted to carbon dioxide and hydrogen with the addition of water in the water-gas-shift reaction. This exothermic reaction occurs at moderate temperature (typically 200 to $500^{\circ} \mathrm{C}$ ) and low pressure (usually a few atmospheres). The residual $\mathrm{CO}$ concentration leaving a water-gasshift reactor (typically about $1 \%$ ) is too high for PEM type fuel cells. Therefore, a preferential oxidation reactor is used to convert most of the remaining $\mathrm{CO}$ to $\mathrm{CO}_{2}(\mathrm{CO}$ concentration after preferential oxidation typically about $10 \mathrm{ppm}$ ) without oxidizing the hydrogen. The exothermic preferential oxidation reaction also operates at moderate temperature (typically 300 to $400^{\circ} \mathrm{C}$ ) and low pressure (usually a few atmospheres).

Fuel processing requirements vary among the alternative fuel cell types because of different sensitivities to $\mathrm{CO}$ and sulfur in the fuel stream. Fuel processing consumes a small portion of the fuel's energy, but the impact on overall efficiency can be minimized by waste heat recovery from the fuel cell stack for higher-temperature fuel cells that use steam reforming. Fuel cells produce $\mathrm{DC}$ power, so conversion to $\mathrm{AC}$ power must be part of the fuel cell system for most applications. Thus, the complete fuel cell system consists of fuel processing, fuel cell stack, and power conversion subsystems, as depicted in Figure 3.

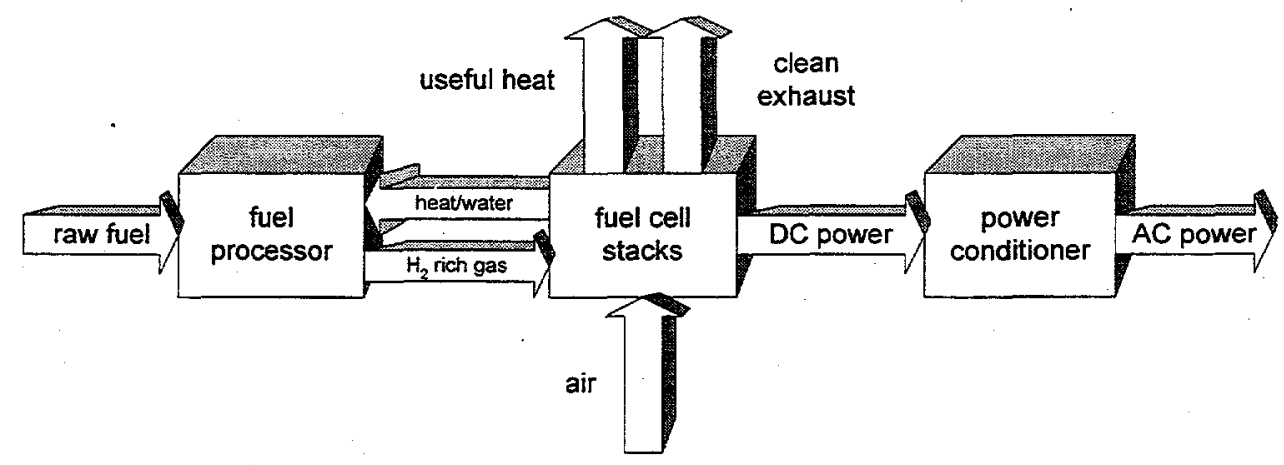

Figure 3. Generic Fuel Cell System

Fuel cells have several features that make them attractive candidates for on-site power generation. Electric conversion efficiency is good, ranging around $40 \%$; overall energy efficiency, including the recovery of steam and/or hot water is about $80 \%$. Air emissions are so low that fuel cells have received exemptions from the standard environmental permitting process in several locales, including Southern California, where air emissions regulations are quite restrictive. $\mathrm{NO}_{\mathrm{X}}$ generation is essentially eliminated because the fuel cell is an electrochemical 
process rather than a high-temperature combustion process. Sulfur or sulfur compounds in the fuel stream can poison catalysts, react with electrolytes, or otherwise reduce cell efficiency (depending on fuel cell type), so these compounds are removed or minimized in the fuel processor.

Unlike many power generating technologies, fuel cells do not rely on size economies-of-scale to reduce cost or improve performance. Fuel cells are currently being developed at sub-kW to multi-MW sizes, which covers practically every possible application of interest to an end-user. High reliability has been demonstrated by over 140 PA units, some with over 40,000 hours of accumulated service. In addition, fuel cells are very quiet and produce clean premium power for servicing sensitive electric loads.

The only significant problem with fuel cells is their high initial cost. The purchase price of an ONSI PA fuel cell (the only fuel cell currently commercially available) is $\$ 3000 / \mathrm{kW}$. While this can be reduced via an ongoing Federal rebate program to $\$ 2000 / \mathrm{kW}$, the cost is still too high to compete with grid-supplied electric power in most locations, even with the cogeneration benefit. Still, if fuel cell technology advances in the next few years match those of the past few years, these costs could be cut in half, resulting in a large number of cost-effective applications. 


\section{Phosphoric Acid Fuel Cells}

Phosphoric acid (PA) is the most mature type of fuel cell technology and the only technology that is currently commercially available. ONSI offers a $200-\mathrm{kW}$ unit at a purchase price of $\$ 600,000$ or $\$ 3000 / \mathrm{kW}$. For the last several years, a Federal government rebate program has reduced the net purchase price to $\$ 2000 / \mathrm{kW}$ for qualified applicants. The latter cost is still too high to compete with grid-supplied electricity and conventionally-generated hot water in most locations, but the added value of premium power, service at remote sites, reduced emissions, high reliability, and low noise increases attractiveness.

ONSI is currently producing the third version of its $200-\mathrm{kW}$ PC- $25^{\mathrm{TM}}$ power plant. Since 1992 , over 140 units have been installed, accumulating over two million hours of service. The oldest of these units have been operating for over 40,000 hours, the original expected design life for the cell stack assembly. The balance of the fuel cell system, including the fuel processor and power conditioner, is expected to last at least 20 years with normal maintenance.

Reliability has been exceptional for an introductory commercial power plant. Several units have run continuously for more than 1 year. The average mean time between forced outages has been 2000 hours, and the annual availability for the latest version of the power plant (the PC-25CTM) is estimated to be $95 \%$. This performance already exceeds that for other small cogeneration power plants based on gas turbines or reciprocating engines.

The ONSI unit converts $36 \%$ of the natural gas fuel energy into electricity and an equal amount into usable waste heat in the form of pressurized hot water. This figure is based on the higher heating value (HHV) of natural gas. Electric and cogeneration efficiencies are $40 \%$ and $80 \%$, respectively, based on the lower heating value (LHV).

The only significant shortcoming of the ONSI fuel cell is its high purchase cost. Considerable progress has been made in the last 5 years to reduce the size and cost of the ONSI unit by about one-third. Further reductions are expected via advances in fuel processor, cell stack, and power conversion design; improved manufacturing processes; and higher volume production.

Improvement in the electrical conversion efficiency is possible too, but must consider the tradeoff between cost and efficiency. Conversion efficiencies in the mid-40s (based on HHV) have been achieved, but at lower current densities and higher pressures compared to the ONSI unit. Cutting the current density in half will generally raise the efficiency by a few percentage points, but will nearly double the size and cost of the stack required to deliver a given power output. Conversely, developments that allow an increase in the current density while maintaining the current conversion efficiency and cell life may be the path toward lower costs per $\mathrm{kW}$. Increasing operating pressure will also increase conversion efficiency by a few points, but has generally resulted in more maintenance problems and shorter cell stack lifetimes to date. PA fuel cells with operating pressures up to 8 atmospheres have been built and tested, but the current ONSI design operates at near 1 atmosphere.

Historically, more than 100 PA fuel cells, ranging from several $\mathrm{kW}$ to a few MW in size, have been built and tested in the U.S., Japan, and Europe. The largest was an 11-MW power plant installed by Tokyo Electric Power Company. The total tested capacity of all units is in excess of $40 \mathrm{MW}$. Current U.S development and application of the PA fuel cell is focused on the ONSI unit. The perception of better long-term prospects (lower costs and higher electric conversion 
efficiencies) has resulted in a shift in R\&D resources towards molten carbonate and solid oxide technologies for stationary applications and the PEM for transportation applications, although the latter is being developed to compete with the PA fuel cell in sub-MW stationary applications, as well. Internationally, several Japanese organizations (e.g., Fuji Electric and Mitsubishi Electric) are still pursuing the development and application of PA fuel cells for both utility and small cogeneration applications. Current European research is less focused on PA as well.

An exploded view of a typical PA cell is shown in Figure 4. The anode and cathodes are made from porous carbon material with channels for fuel and oxidant, respectively. The electrolyte side of each electrode is covered by a thin platinum catalyst layer, supported by carbon particles, and held together by a polymeric binder, usually polytetrafluoroethylene (PTFE). Typical catalyst loadings are $0.1 \mathrm{mg} / \mathrm{cm}^{2}$ on the anode and $0.5 \mathrm{mg} / \mathrm{cm}^{2}$ on the cathode. ${ }^{4}$ Phosphoric acid is held in the middle of the cell by a matrix of silicon carbide. A thin glassy carbon plate is used for the separators. Reactions occur in the three-phase zone within each catalyst layer where the phosphoric acid (liquid), platinum (solid) and hydrogen or oxygen (gas) are simultaneously present.
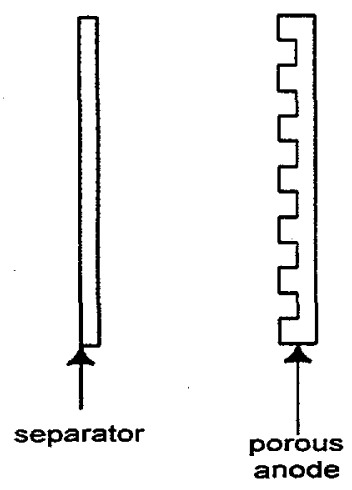
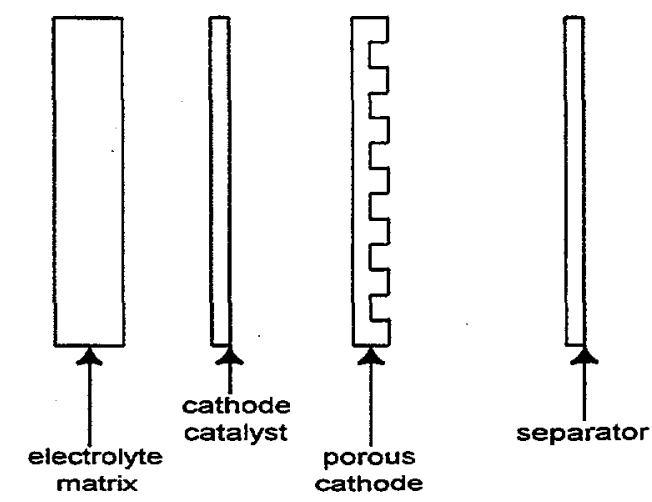

Figure 4. Phosphoric Acid Cell

Hydrogen reacts at the anode to produce protons and electrons. The protons are conducted through the electrolyte to the cathode while the electrons travel to the cathode through an external circuit (the load). The protons, electrons, and oxygen combine at the cathode to form water. Anode, cathode, and overall fuel cell reactions are summarized below.

$$
\begin{array}{ll}
\text { Anode: } & \mathrm{H}_{2} \rightarrow 2 \mathrm{H}^{+}+2 \mathrm{e}^{-} \\
\text {Cathode: } & 2 \mathrm{H}^{+}+1 / 2 \mathrm{O}_{2}+2 \mathrm{e}^{-} \rightarrow \mathrm{H}_{2} \mathrm{O} \\
\text { Overall: } & \mathrm{H}_{2}+1 / 2 \mathrm{O}_{2} \rightarrow \mathrm{H}_{2} \mathrm{O}
\end{array}
$$

The fuel gas supplied to the anode is not generally pure hydrogen, but a mixture of hydrogenrich gases produced in the fuel processor from methane or another relatively light hydrocarbon. Methane is commonly converted to (predominately) $\mathrm{H}_{2}$ and $\mathrm{CO}_{2}$ via reforming and water-gasshift reactions. These reactions are summarized below. The latter reaction does not run to

\footnotetext{
${ }^{4}$ More catalyst is required at the cathode because reaction kinetics are poorer for the oxygen reduction reaction than they are for the hydrogen oxidation reaction at the anode.
} 
completion, but a residual $\mathrm{CO}$ concentration of $1 \%$ is achievable and tolerable by the PA fuel cell. Higher $\mathrm{CO}$ concentrations will poison the catalyst, however, so care must be taken. Still, the allowable CO concentration for a PA fuel cell is 1000 times that allowed for a PEM fuel cell, which must include an additional step in its fuel processor to reduce the CO concentration to no more than $10 \mathrm{ppm}$. The fuel processor must also remove any sulfur from the feed gas to limit $\mathrm{H}_{2} \mathrm{~S}$ and $\mathrm{COS}$ in the fuel gas to a combined $50 \mathrm{ppm}$ or $\mathrm{H}_{2} \mathrm{~S}$ alone to $20 \mathrm{ppm}$. Otherwise, higher levels will poison the anode catalyst. Catalyst poisoning, whether caused by $\mathrm{CO}, \mathrm{H}_{2} \mathrm{~S}$, or $\mathrm{COS}$, decreases catalyst activity, hence cell reaction rates and performance. Fortunately, performance reverts to normal levels once poison concentrations drop to tolerable levels.

$$
\begin{array}{ll}
\text { Reformer: } & \mathrm{CH}_{4}+\mathrm{H}_{2} \mathrm{O} \rightarrow \mathrm{CO}+3 \mathrm{H}_{2} \\
\text { Shift Reactor: } & \mathrm{CO}+\mathrm{H}_{2} \mathrm{O} \rightarrow \mathrm{CO}_{2}+\mathrm{H}_{2} \\
\text { Overall: } & \mathrm{CH}_{4}+2 \mathrm{H}_{2} \mathrm{O} \rightarrow \mathrm{CO}_{2}+4 \mathrm{H}_{2}
\end{array}
$$

Fuel energy not converted to electricity must be removed via an active cooling system.

Fortunately, the PA fuel cell operates at a temperature (about $200^{\circ} \mathrm{C}$ ) that produces waste heat at a temperature that is high enough to produce low pressure steam or pressurized hot water. Heat is removed via cooling tubes placed between approximately every 5 th cell. The cooling fluid may be air, water, water/steam, or a heat transfer oil. 


\section{Proton Exchange Membrane Fuel Cells}

The proton exchange membrane (PEM) fuel cell, also known as a solid polymer electrolyte (SPE) fuel cell, uses a sulfonated fluoropolymer similar to Teflon ${ }^{T M}$ as the electrolyte. The most commonly used material is perfluorosulphonic acid. The membrane is sandwiched between two platinum impregnated porous carbon electrodes, with the three components collectively referred to as the membrane electrode assembly or MEA. The electrodes are usually coated with a hydrophobic material to minimize the "flooding" of electrode pores with water, causing poor diffusion of gas to reaction sites within the electrodes, hence poor cell performance.

Metal, graphite, or graphite composite plates serve to separate one cell from the next, collect current, distribute electrode reactants, and provide a cooling channel to remove waste heat. Some designs use more than one component to accomplish these "plate" functions. Waste heat removal is generally accomplished by pumping a fluid (usually water) through the channels, but forced air or natural convection from fins has also been considered for smaller cell stacks. Although design and material details differ, the basic cell components are identical to those shown for the PA cell in Figure 4. The principal difference is the electrolyte, which is a solid polymeric acid rather than a liquid inorganic acid.

The PEM material is limited to a maximum operating temperature of about $100^{\circ} \mathrm{C}$; typically, cells are designed to operate at about $80^{\circ} \mathrm{C}$. The lower operating temperature allows the cell to start very quickly, within a few seconds. The cell may also operate at very high current densities, which allows compact and lightweight power systems. Thus, PEM fuel cells look especially attractive for transportation applications, and are well suited for any applications where volume and weight are important, such as in space, in submarines, or for portable power supplies. Compactness will be at least a moderate advantage for building applications too. In addition, its lower operating temperature and solid electrolyte may result in a safer product compared to other fuel cell options.

Unfortunately, a lower operating temperature has some drawbacks. The lower temperature causes poorer reaction kinetics, which generally requires higher catalyst loadings and/or more sophisticated catalyst utilization strategies to achieve adequate reaction rates. Lower operating temperatures also result in lower temperature waste heat, which is a detriment for prospective cogeneration applications and for use in any endothermic fuel processing reaction. For example, PEM fuel cells are unable to produce low pressure process steam (e.g., 30 psia steam). PEM waste heat, collected in the form of hot water, should still be warm enough for space and domestic water heating, however.

The solid polymer provides an electrolyte that is non-corrosive and capable of withstanding high pressure differentials, but must be well hydrated to maintain good conductivity. Water management is an issue for PEM fuel cells, but one that can be controlled. Protons migrating from the anode to the cathode drag water molecules along, causing that portion of the membrane closer to the anode to dry out. This electro-osmotic pumping of water is compounded by the reaction of hydrogen and oxygen to form more water at the cathode 5 . Some back-diffusion of water occurs as a result of the concentration gradient, but a gradient is still formed. Excess water is particularly troublesome at the cathode because it is migrating in the opposite direction of the

\footnotetext{
${ }^{5}$ With its operating temperature below $100^{\circ} \mathrm{C}$, water is produced as a potable liquid, which could be a valuable co-product.
} 
oxygen molecules. These problems have been overcome by designs that quickly remove water from the cathode and by humidifying the fuel gases contacting the anodes. Care must be taken not to add too much water to the fuel gas, however, or the fuel will have trouble diffusing to reactive sites on the anode. Alternative membranes that are less sensitive to drying out are also being developed. PEM fuel cell water production and transport mechanisms are illustrated in Figure 5.

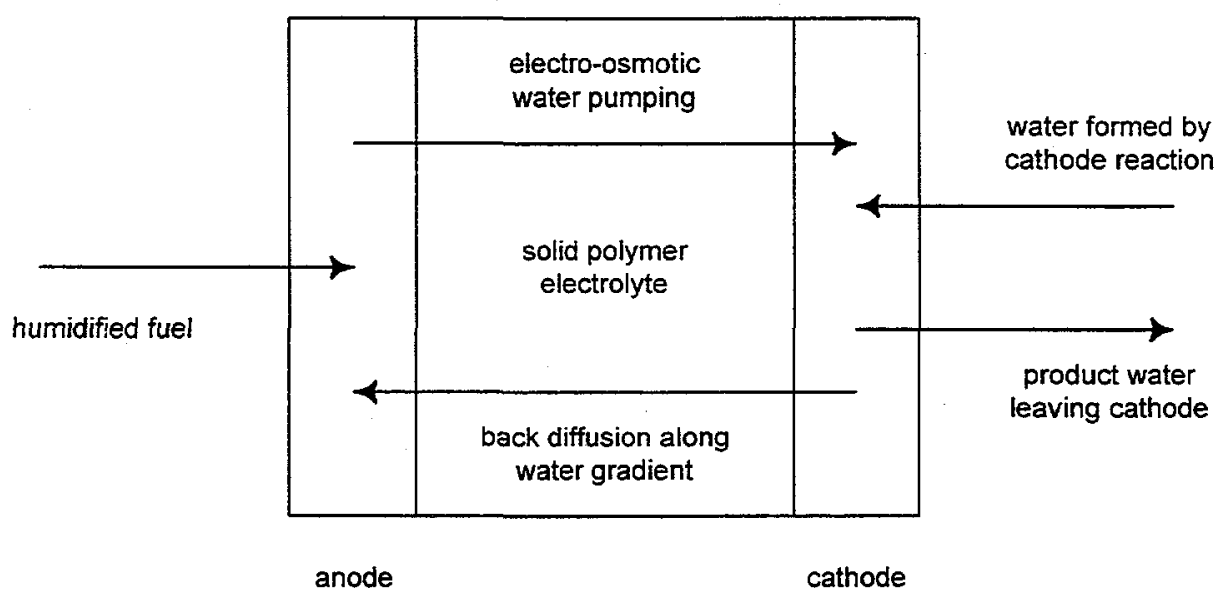

Figure 5. PEM Cell Water Balance

The electric and cogeneration conversion efficiencies of the PEM fuel cell are expected to be similar to the PA fuel cell. Again, significant variation is possible, depending on the fuel and oxidant, and fuel and oxidant pressurization, as well as cell component design. With lower temperature waste heat, more fuel may be required for endothermic fuel processing reactions, so the overall system electrical conversion efficiency may be slightly less.

PEM systems are currently being developed for applications ranging in size from about $100 \mathrm{~W}$ to $1 \mathrm{MW}$. PEM fuel cells are viewed as a substitute for batteries at the low end of this range, where the fuel cell would typically be integrated with some form of hydrogen storage. Most of the PEM development effort is focused on vehicular applications with fuel cells ranging in size from 10 to $50 \mathrm{~kW}$. Early systems have incorporated hydrogen storage, but parallel work is ongoing to develop smaller fuel processing systems as well. Larger systems are being developed to compete with the current commercial PA fuel cell for end-use stationary power supplies.

Ballard Power Systems initiated tests in 1997 on their first generation, 250-kW stationary PEM fuel cell power plant. Tests on their second generation model are expected to begin in 1999. Ballard has developed prototype PEM fuel cell systems as small as $25 \mathrm{~W}$ and has plans for eventually developing products ranging from approximately $100 \mathrm{~W}$ to $1 \mathrm{MW}$. Several companies, namely Analytic Power, Avista Labs, H Power, Plug Power, and Northwest Power Systems, are developing stationary PEM fuel cells with an initial focus on the residential market. Market introduction of PEM fuel cells for both residential and commercial applications is expected by 2001 . 
Like all current fuel cells, the PEM suffers from being too costly for most applications. Previously, poorer reaction kinetics stemming from low-temperature operation required extremely high platinum catalyst loadings at both the anode and cathode to achieve adequate reaction rates. However, much work has been done to reduce platinum catalyst loadings to near that required for the PA fuel cell (about $0.4 \mathrm{mg} \mathrm{Pt} / \mathrm{cm}^{2}$ ). Cost reduction efforts are now focused on developing less expensive, but satisfactorily performing substitutes for the PEM membrane and separator plates. Much of the focus for the latter component has been on developing metal or graphite composite separators.

Basic cell chemistry is identical to that in the PA fuel cell. Hydrogen reacts at the anode to produce protons and electrons. The protons are conducted through the electrolyte to the cathode, while the electrons travel to the cathode through an external circuit (the load). The protons, electrons, and oxygen combine at the cathode to form water. Anode, cathode, and overall fuel cell reactions are summarized below.

$\begin{array}{ll}\text { Anode: } & \mathrm{H}_{2} \rightarrow 2 \mathrm{H}^{+}+2 \mathrm{e}^{-} \\ \text {Cathode: } & 2 \mathrm{H}^{+}+1 / 2 \mathrm{O}_{2}+2 \mathrm{e}^{-} \rightarrow \mathrm{H}_{2} \mathrm{O} \\ \text { Overall: } & \mathrm{H}_{2}+1 / 2 \mathrm{O}_{2} \rightarrow \mathrm{H}_{2} \mathrm{O}\end{array}$

The platinum catalyst at the anode is much more sensitive to $\mathrm{CO}$ than in the PA fuel cell, so fuel processing of hydrocarbons requires an extra step. In addition to the steam reforming and watergas-shift reactions previously described for PA fuel cells, PEM fuel cells require an additional preferential oxidation step to reduce the concentration of $\mathrm{CO}$ leaving the water-gas-shift reactor (typically, about $1 \%$ ) to about $10 \mathrm{ppm}$. As its name suggests, the preferential oxidation reactor converts the majority of residual $\mathrm{CO}$ into $\mathrm{CO}_{2}$ without also oxidizing $\mathrm{H}_{2}$. Quite obviously, the additional fuel processing step adds an economic burden to the PEM system. 



\section{Molten Carbonate Fuel Cells}

The molten carbonate (MC) fuel cell uses a mixture of lithium and potassium carbonate as its electrolyte. Typically, this fuel cell operates at a temperature of $650^{\circ} \mathrm{C}$, with the carbonate in liquid form. MC fuel cells are commonly thought of as second-generation technology that will eventually replace PA fuel cells for stationary power generation applications. At this point, the technology is still in the development and testing phase, however.

Its higher operating temperature results in several advantages relative to the PA fuel cell. At $650^{\circ} \mathrm{C}$, internal reforming of lighter hydrocarbons (such as methane) is possible, which eliminates the need for a separate fuel processor and heat exchangers for transferring waste heat from the cell stacks to the fuel processor. The higher operating temperature also results in waste heat that is able to serve a much broader range of potential process heating applications. The higher temperature also improves reaction kinetics, eliminating the need for rare metal catalysts, such as platinum. Although the higher operating temperature also reduces the Gibbs free energy 6 that can be theoretically converted to electricity, the other benefits of a higher operating temperature noted above, coupled with relatively low ohmic losses, results in a higher electrical conversion efficiency (about 50\%, based on the fuel's higher heating value, for a mature, commercial product) for the MC fuel cell compared to other fuel cells. Its higher operating temperature does not come without some compensating disadvantages, however. In particular, molten carbonate salts are very corrosive, and the cell chemistry is rather complicated and causes unwanted side reactions.

The principal MC cell reactions are different from the PA or PEM fuel cells. Hydrogen reacts at the anode with carbonate ions to form water, carbon dioxide and two electrons. The electrons flow through an external load to the cathode, where they combine with oxygen and carbon dioxide to form carbonate ions. The carbonate ions migrate through the electrolyte from the cathode to the anode to complete the circuit. These reactions are summarized below. Note that carbon dioxide must be externally recycled from the anode to the cathode, which places a burden on the MC system compared to other fuel cells.

$$
\begin{array}{ll}
\text { Anode: } & \mathrm{H}_{2}+\mathrm{CO}_{3}^{2-} \rightarrow \mathrm{H}_{2} \mathrm{O}+\mathrm{CO}_{2}+2 \mathrm{e}^{-} \\
\text {Cathode: } & 1 / 2 \mathrm{O}_{2}+\mathrm{CO}_{2}+2 \mathrm{e}-\rightarrow \mathrm{CO}_{3}{ }^{2-} \\
\text { Overall: } & \mathrm{H}_{2}+1 / 2 \mathrm{O}_{2} \rightarrow \mathrm{H}_{2} \mathrm{O}
\end{array}
$$

In contrast to the PA and PEM fuel cells, water is produced at the anode in a MC fuel cell, which facilitates steam reforming and water-gas-shift reactions. Designs have been developed for both direct and indirect internal reforming. In the former, the reforming and shift reactions occur at the anode; while in the latter, the reactions occur in a chamber directly adjacent to the anode. Direct internal reforming offers more integrated heat transfer, and the removal of hydrogen via the anode oxidation reaction increases the generation of hydrogen via the water-gas-shift reaction. The problems with direct internal reforming stem from the complexities of designing a device to accommodate all three reactions simultaneously. Direct and indirect internal reforming concepts are illustrated in Figure 6.

\footnotetext{
${ }^{6}$ The theoretical maximum electricity production from a fuel cell is equal to the change in Gibbs free energy for a reaction, which differs from the change in enthalpy for a reaction by the change in entropy multiplied by the reaction temperature, i.e., $\Delta \mathrm{G}=\Delta \mathrm{H}-\mathrm{T} \Delta \mathrm{S}$.
} 


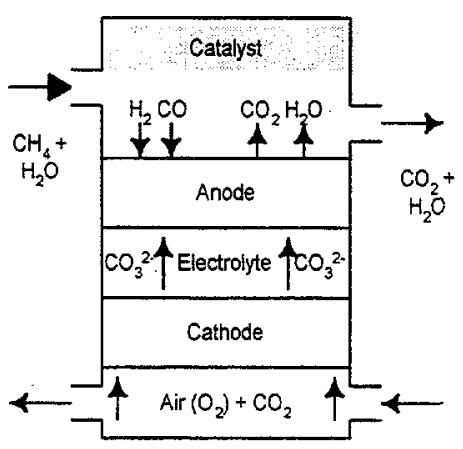

Direct

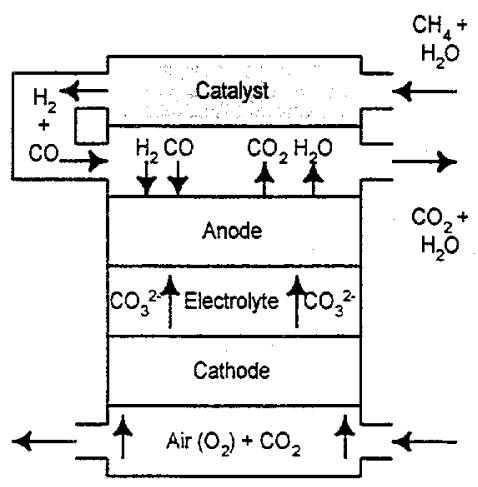

Indirect

Figure 6. Direct and Indirect Internal Reformers

Molten carbonate is an extremely corrosive material, which places severe demands on cell stack materials, particularly at the cathode with its oxidizing environment. Porous nickel is the most commonly used cathode material. During initial operation, the nickel is transformed into lithiated nickel oxide by the combination of its lithium carbonate bath and oxidizing atmosphere. Unfortunately, the lithiated nickel oxide is slightly soluble in the molten carbonate, which limits its lifetime. Alternative cathode materials are one subject of current research.

Operating conditions at the anode are less severe than at the cathode. Porous nickel is most commonly used and doubles as the catalyst for the hydrogen oxidation reaction. Chromium is typically added to make the anode less subject to sintering and creep, which results from the combination of high-temperature operation and the compressive forces necessary for stack operation. Compressive forces are required to ensure intimate contact between the conductive surfaces of individual stack elements and to maintain proper sealing. Partial substitution of copper for nickel is being investigated as a potential cost reduction measure.

The liquid carbonate electrolyte is immobilized in a semisolid mixture with a ceramic powder, usually lithium aluminate. The electrolyte is held within the ceramic via capillary forces, and the mixture is impermeable to reacting gases at the two electrodes. In addition, though relatively stiff, the mixture will deform under changes in temperature and pressure to maintain its seal. Capillary forces are also used to control the migration of electrolyte into the electrodes by properly matching the distribution of pore sizes within the electrodes and electrolyte matrix. This approach to controlling the liquid-gas interface contrasts that of the PA fuel cell, which uses a hydrophobic material dispersed within the electrodes. No known material exists that can provide the same service in the MC fuel cell environment.

The currently preferred electrolyte is $62 \%$ lithium and $38 \%$ potassium carbonate. Lithium carbonate has a higher ionic conductivity, which results in lower ohmic losses, but suffers from lower gas solubility and diffusivity, which results in slower reaction rates. In addition, lithium carbonate is more corrosive. The $62 / 38$ mixture represents a compromise with the best overall performance characteristics. 
$\mathrm{CO}$ does not present a contaminant problem for $\mathrm{MC}$ fuel cells like it does for PA and, especially, PEM fuel cells. In fact, as discussed above, $\mathrm{CO}$ is effectively utilized as a fuel via the water-gasshift reaction. Sulfur compounds present serious problems, however, and need to be removed from the fuel gas. $\mathrm{H}_{2} \mathrm{~S}$ will block reaction sites for the water-gas-shift and hydrogen oxidation reactions. $\mathrm{SO}_{2}$, occurring in the fuel gas or created via oxidation of $\mathrm{H}_{2} \mathrm{~S}$ when the anode gas exhaust is combusted, will combine with the electrolyte to form sulfate. The result is a reduction in cell voltage and conversion efficiency. The tolerance for sulfur in the form of $\mathrm{H}_{2} \mathrm{~S}$ or $\mathrm{SO}_{2}$ depends on cell operating conditions, and reported requirements vary. Concentrations less than $10 \mathrm{ppm}$ will likely be required, and may need to be $1 \mathrm{ppm}$ or lower.

Electrolyte loss and redistribution is a significant problem for $\mathrm{MC}$ fuel cells that reduces performance over the life of a cell stack. Electrolyte is lost via corrosion and volatilization processes. Included here are losses at the "wet" electrolyte seal between metal housing components. Loss of electrolyte results in redistribution to satisfy equilibrium of capillary forces. Electrolyte redistribution also occurs as a result of changes in electrode pore size distribution, which occurs rapidly early in life, but continues slowly throughout the life of a cell.

The components of a MC cell are essentially the same as those shown in Figure 4 for the PA fuel cell, with a couple of differences. Separate catalysts are not required; the nickel-based electrodes provide this function in combination with providing surface reaction sites. In addition, reactant and product flow channels are generally incorporated into the separator rather than the electrodes. Some designs may include distinct current collectors if that function is not directly incorporated into the separator. Typical anode, cathode, and electrolyte materials were described above. The separators and current collectors are usually made from stainless steel, with the side facing the anode coated with a layer of nickel. The elastic nature of MC cell components allows individual cells to be scaled up to larger sizes compared to the SO fuel cell, which should help reduce manufacturing costs for commercial systems.

Reactant gases are fed to individual cells via either external or internal manifolding. The external type consists of two sets of manifolds (inlet and outlet fuel and oxidant) that are attached externally to the four sides of the cell stack. With internal manifolding, four inlet and outlet ports are positioned at the top or bottom of the cell stack. Additional flow distribution pathways are incorporated within the stack. The two options are illustrated in Figure 7. External manifolds result in low pressure drop and are easily manufactured, but suffer from gas leakage through the gasket between the stack and manifold. Internal manifolds effectively eliminate gas leakage and simplify stack compression, but increase the size and complexity of the separator plate.

Like all fuel cells, operating the MC system at pressure increases its conversion efficiency, but generally causes other problems that reduce operating life. Both of the two principal MC developers in the U.S., MC Power and Energy Research Corporation (ERC), operate their stacks at 3 atmospheres. Operating at pressure will increase the electric conversion by several percentage points, but increases the solubility of the $\mathrm{NiO}$ cathodes, hence reducing cell and stack life. Quite obviously, this problem is a key development issue.

MC fuel cells are currently being developed by several U.S., Japanese, and European companies. Two significant technology demonstrations were recently completed in the U.S. by ERC and MC Power. 

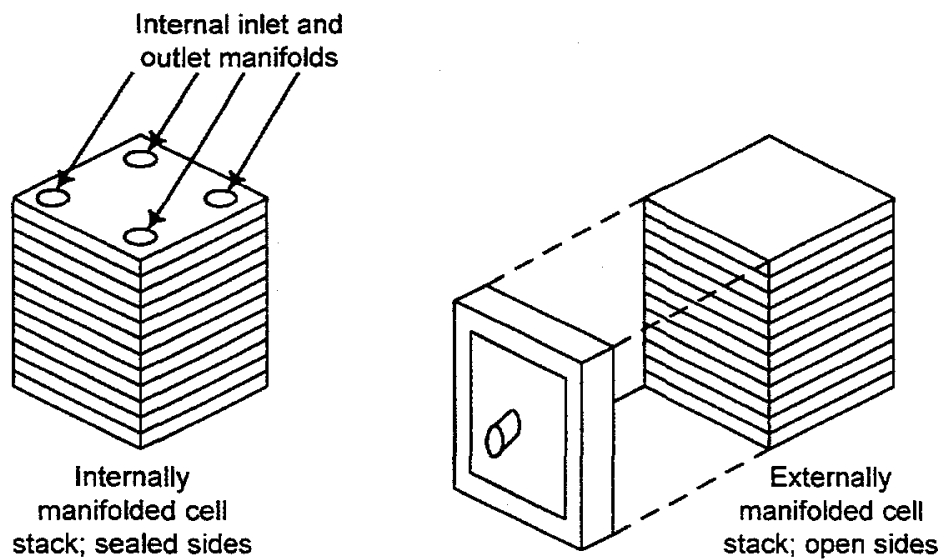

One of four external inlet and outlet manifolds; one on each side

Figure 7. Internal and External Manifolding

A 1.8-MW MC power plant using ERC cell stacks operated for about 4000 hours in 1996 and 1997 at a test site hosted by the City of Santa Clara, California. Total power production was $1710 \mathrm{MWh}$ with an electrical conversion efficiency of $43.6 \%$ based on the fuel's lower heating value. Unfortunately, the unit suffered from a short circuit caused by carbonization of a glue used as a sealant. The result was a loss of one-half of the plant's original capacity. After isolating the faulty portion, the plant was restarted and run for a few months, when accumulating electrical problems caused the plant to be shut down permanently. ERC has since developed an improved $250-\mathrm{kW}$ stack that will be the building block for its commercial units. Testing of the new stack was initiated in 1998 and will continue in 1999. Testing of a 1-MW module is planned for 2000, with the first commercial product planned for 2001 .

A $250-\mathrm{kW}$ (actual maximum output was $210 \mathrm{~kW}$ ) MC power plant using MC Power cell stacks operated for about 3000 hours at a test site hosted by the U.S. Navy Air Station at Miramar, California. Total power production was $160 \mathrm{MWh}$ (conversion efficiency not reported). In addition, the test plant produced about 300,000 pounds of 110 psig steam. The plant experienced minor problems with the hot gas blower, turbocharger, and control system, but was eventually shut down because of a much higher than expected pressure drop across the stack. MC Power has since addressed the problems described above and developed new designs for the stack and balance-of-plant. Two new stacks ( $75 \mathrm{~kW}$ and $175 \mathrm{~kW}$ ) are scheduled for testing in 1999 at the Miramar facility. The first commercial prototype is expected in 2000 or 2001 , and the first true commercial unit is planned for 2002 . The commercial product is expected to be a $500-\mathrm{kW}$ skidmounted unit. 


\section{Solid Oxide Fuel Cells}

As its name implies, the solid oxide ( $\mathrm{SO}$ ) fuel cell is constructed entirely of solid components, including its ceramic electrolyte. Adequate ionic conductivity is only achieved at very high temperature, however; the most mature version of this fuel cell operates at $1000^{\circ} \mathrm{C}$. Like the PEM and MC fuel cells, the SO fuel cell is currently in the development and testing phase. Although it may be the least mature of all the fuel cells discussed in this report, its developers are hoping that commercial products will be available within the next 5 years.

By eliminating the liquid phase, the SO fuel cell is simpler in concept compared to other fuel cells and allows more freedom in designing the cell components. Corrosion problems are significantly reduced and electrolyte management becomes a non-issue. Its high operating temperature creates disadvantages as well as advantages, however. On the plus side, electrode reactions proceed very quickly even without rare metal catalysts, such as platinum, and the waste heat is hot enough to consider gas turbines as well as steam turbines for bottoming cycles. In addition, internal reforming is even more effective than for MC fuel cells. On the other hand, the Gibbs free energy available for conversion to electricity is the lowest of all the fuel cells, and material problems are severe. The net effect of these pros and cons on expected electric conversion efficiency is a projected value of 45 to $50 \%$ for a mature system, based on the higher heat value. Coupled with a gas turbine bottoming cycle, this figure could be 60 to $65 \%$, on the same basis. Cell materials must have nearly matching thermal expansion coefficients and meet the usual fuel cell component requirements. Therefore, several developers are pursuing SO fuel cell systems that can be operated at temperatures several hundred ${ }^{\circ} \mathrm{C}$ lower than the current $1000^{\circ} \mathrm{C}$ benchmark.

Anode and cathode reactions for the SO fuel cell parallel that for the MC fuel cell, with the oxide ion substituting for the carbonate ion as the ionic carrier through the electrolyte. Hydrogen reacts at the anode with oxide ions to form water and two electrons. The electrons flow through an external load to the cathode, where they combine with oxygen to form an oxide ion. The oxide ion then migrates through the electrolyte to the anode to complete the circuit. These reactions are summarized below. Like the MC fuel cell, water produced at the anode aids the process of internal fuel reforming.

$\begin{array}{ll}\text { Anode: } & \mathrm{H}_{2}+1 / 2 \mathrm{O}_{2} 2-\rightarrow \mathrm{H}_{2} \mathrm{O}+2 \mathrm{e}^{-} \\ \text {Cathode: } & 1 / 2 \mathrm{O}_{2}+2 \mathrm{e}-\rightarrow \mathrm{O}_{2}^{2-} \\ \text { Overall: } & \mathrm{H}_{2}+1 / 2 \mathrm{O}_{2} \rightarrow \mathrm{H}_{2} \mathrm{O}\end{array}$

The combination of very high temperature and an oxidizing atmosphere creates a severe operating environment at the cathode, which limits the choice of material. In addition to the usual requirements of cathode materials (e.g., high electroactivity for oxygen reduction, high conductivity, chemically stable with other components), the high temperature of the SO fuel cell places a premium on matching the thermal expansion coefficients of the cathode and other cell components. Noble metals could be used, but are extremely expensive. Oxides, such as zirconia, can withstand the cathode environment and are compatible with other cell components, but have poor electronic conductivity. The currently preferred cathode material is strontiumdoped lanthanum manganite. This material possesses good ionic and electronic conductivities and adequate thermal expansion characteristics, but work continues to find a material that improves on the latter. 
Material requirements for the anode, which operates in a reducing environment, are less stringent. Again, the need for thermal expansion characteristics that are compatible with other cell components is especially important for the high temperature SO fuel cell, in addition to the usual expectations for an anode (e.g., high conductivity, chemically stable, effective oxidation catalysis). Porous nickel satisfies most of these requirements, but its thermal expansion coefficient is too high to use by itself. The currently preferred material is a nickel-zirconia cermet (in general, an intimate mixture of ceramic and metal materials, in this case a porous mixture of nickel and zirconia particles), which yields a satisfactory combination of conductivity and thermal expansion coefficient.

In general, electrolytes should have high ionic conductivity, low electronic conductivity, be stable in both anode and cathode environments, and not allow fuel crossover to the cathode. Again, thermal expansion compatibility with other cell components is especially important for the SO fuel cell. The material meeting these requirements and used as the electrolyte in SO fuel cells is yttria-stabilized zirconia.

The solid state nature of the SO fuel cell, combined with the need to accommodate the rigors of a high-temperature operating environment, have yielded three distinct types of cell structures, two of which are significantly different than the cell structures of other fuel cells. The most mature design is a tubular cell developed by Siemens-Westinghouse. Horizontal and vertical cross sections of this cell are shown in Figure 8. Air is preheated as it flows down a concentric injection tube, then back up the outside of the injection tube past the cathode. Fuel flows around the outside of the tube, against the anode. Several tubes are bundled together in a series-parallel arrangement within a shell that serves to contain the fuel and as cathode and anode busses. Unreacted fuel and excess air are mixed and combusted in an adjacent chamber to provide initial air preheating. The tubular design essentially eliminates sealing problems, but does have a relatively long current path around the circumference of the cell, which tends to increase ohmic losses.

In general, most fuel cells include a separator, in addition to the cathode, anode, and electrolyte. As previously described, the separator provides electrical series connection between cells and physically separates the fuel and oxidant streams. The separator may also serve current collection and reactant distribution purposes. These same functions must be served in a SO fuel cell, but in a bundle of tubular cells, the only duty of the "separator" is to provide an electronic connection between two adjacent cells. Thus, this device is commonly referred to as an "interconnect" when describing a SO fuel cell. The interconnect must have high electronic conductivity, no ionic conductivity, be chemically stable in both anode and cathode operating environments, and have thermal expansion characteristics that are compatible with other cell components. The current material of choice is lanthanum chromite.

A monolithic SO cell designed for coflow of air and fuel is shown in Figure 9. Crossflow designs have also been developed. Monolithic cells offer the potential of higher power density than the tubular design, but suffer from higher thermal stresses that can lead to premature failure. Crossflow designs offer simpler fuel and oxidant manifolding, but a more complex structure. 


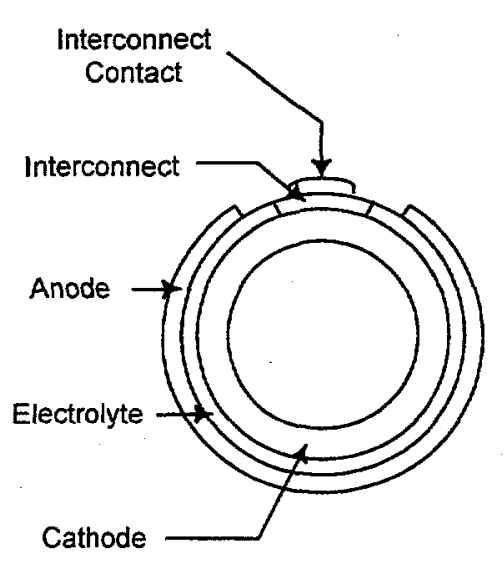

Tubular Cell Horizontal Cross Section

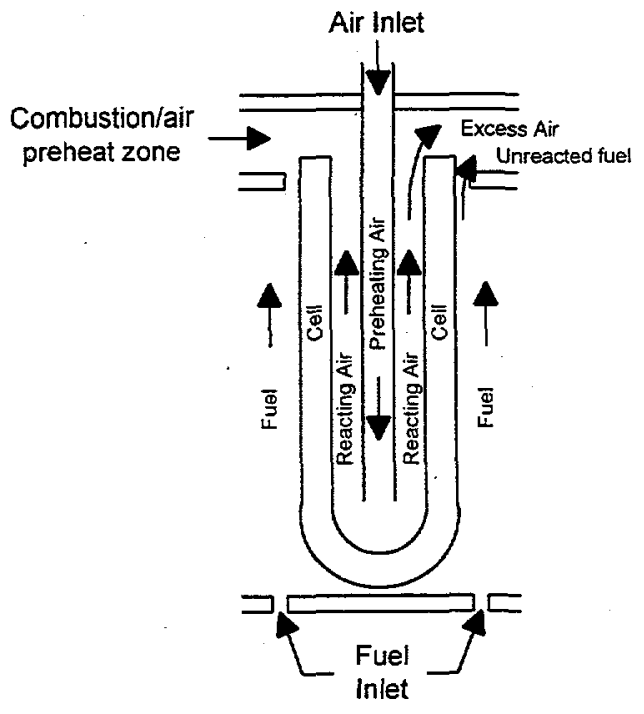

Tubular Cell Vertical Cross Section

Figure 8. Tubular SO Cell

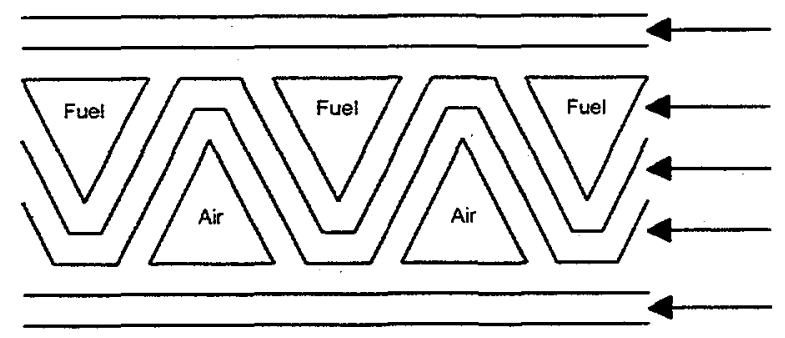

Interconnect

Anode

Electrolyte

Cathode

Interconnect

Figure 9. Monolithic SO Cell

The planar SO cell design is similar to that used for other fuel cells, as depicted in Figure 4 for the PA fuel cell. Like the MC fuel cell, the SO fuel cell does not require the separate catalyst layer shown in Figure 4, and the fuel and oxidant flow channels are usually incorporated into the separator. Like the monolithic design, planar cells offer the potential of higher power density compared to tubular cells. Monolithic cell components are sintered as a whole, while planar cells are assembled from separately sintered components. This simplifies the sintering process, but complicates the cell assembly process and makes it difficult to eliminate gas leakage between cell components. Compressive seals, used successfully in other fuel cells, impart too much stress for the ceramic materials used in SO fuel cells. 
Fuel contaminants present relatively small problems for SO fuel cells. Carbon monoxide is either oxidized directly or combines with water at the anode to form hydrogen and carbon dioxide via the water-gas-shift reaction. At its high operating temperature, lighter hydrocarbons can be internally reformed without any catalyst. Heavier hydrocarbon fuels, such as diesel and JP-8, have also been internally reformed successfully in SO fuel cells, although care must be taken to provide adequate steam to prevent coking. Even sulfur compounds present relatively modest problems. Hydrogen sulfide concentrations of $50 \mathrm{ppm}$ will lower cell efficiency by about $5 \%$, but the degradation reverses once the contaminant is removed. Still, care must be taken to ensure that sulfur compounds, including those added to natural gas as a safety oderant, are removed prior to entering the cell stack.

As suggested above, a key issue for SO fuel cells is to develop materials that can withstand the high operating temperature environment and the associated thermal expansion requirements. Designs must also be developed that allow lower manufacturing costs because material costs are already quite low (less than $\$ 20 / \mathrm{kW}$ ). Monolithic and planar design development must focus on thermal compatibility and sealing issues, respectively.

Many companies in the U.S., Japan, and Europe are developing SO fuel cells, mostly for stationary applications, but ranging in size from $500 \mathrm{~W}$ for portable power applications to multiMW systems for utility and industrial applications. U.S. developers include SiemensWestinghouse, Technology Management, Inc., SOFCo, and Ztek.

As noted above, Siemens-Westinghouse is pursuing development of the more mature tubular designs for multi-MW combined-cycle applications, while the other companies are working with monolithic or planar designs. At this point, testing has been completed on two $25-\mathrm{kW}$ Siemens Westinghouse modules. One module was operated for over 5000 hours at the Southern California Edison Company's Highgrove Generating Station. The module produced up to $27 \mathrm{~kW}$ while operating on natural gas, diesel, and JP-8 fuels. Performance degradation was less than $1 \%$. The second module, tested in Japan by Osaka Gas and Tokyo Gas, operated for more than 1 year on natural gas with no performance degradation. The tubular cell used in the $25-\mathrm{kW}$ modules has been scaled up to the size Siemens-Westinghouse plans to use for its commercial systems. Testing of a 100-kW module, based on the commercial-size cell, started in 1998 at a Dutch utility. The test ran for about 4000 hours before being interrupted to resolve performance problems. Siemens-Westinghouse has since rectified two material problems and expects testing to resume in 1999. Testing of a SO fuel cell integrated with a gas turbine will be the next step. Commercial power plants with capacities ranging from 0.5 to $5 \mathrm{MW}$ are currently planned.

Ztek conducted tests on a $25-\mathrm{kW}$ SO system in 1998 . They plan on using a stack of the same size as a building block for their SO fuel cell/gas turbine hybrid. Demonstration of a $250-\mathrm{kW}$ system, built from 7- to $25-\mathrm{kW}$ SO stacks and a $50-\mathrm{kW}$ gas turbine, is planned for later in 1999 . Technology Management, Inc. is developing the 500-W portable unit noted above while SOFCo is targeting the development of commercial products in the $10-$ to $50-\mathrm{kW}$ range. 


\section{Cost and Performance Characteristics}

Expected long-term (in 7 to 10 years) cost and performance characteristics were developed for each of the principal fuel cell technologies, in addition to current (1998) characteristics for the PA fuel cell. The characterizations were based on information gathered by reviewing published literature and communicating with fuel cell industry representatives, with supplemental assumptions by PNNL. These data are presented in Appendix A. General cost and performance trends are discussed in this section.

\section{Phosphoric Acid Fuel Cell}

Except for its capital cost, all other characteristics of ONSl's PC-25 ${ }^{\mathrm{TM}}$ are comparable or superior to competing options (e.g., diesel generators or small gas turbines) for commercial-size power or cogeneration applications. Thus, the future emphasis for product development will likely be on reducing initial cost through design and/or manufacturing process improvements. As a result, the most significant change forecast for future PA fuel cell characteristics is a reduction in initial capital cost and the corresponding interim capital replacement cost. Projections for the long-term reflect opinions regarding potential mature PA fuel cell costs. The cost reductions projected will likely require an increase in sales and production volume, which is not likely to occur unless the initial cost comes down, so design and manufacturing process improvements will likely be required.

Note that projected PA fuel cell heat rates are the same or only slightly better than the current capability. In fact, more efficient demonstration model PA fuel cells have already been constructed. In general, fuel cell efficiency can be improved by increasing the operating pressure and/or decreasing the current density. Unfortunately, such design changes directly lead to increased costs and/or reduced life for the cell stack. With initial cost the only significant deficiency of the PC- $25^{\mathrm{TM}}$ for the commercial market, the projections assume future efficiency improvements will be sacrificed for lower costs until the latter drops to about $\$ 1500 / \mathrm{kW}$.

The moderately good heat rate of the PA fuel cell will probably limit its application to the commercial market even if an installed cost of $\$ 1500 / \mathrm{kW}$ is achieved. Better performance and lower costs are required to compete in the industrial and utility markets, where combined-cycle plants provide stiff competition. The PEM fuel cell appears to be its most likely challenger in the commercial market, with similar performance (although lower-temperature cogenerated thermal energy) and potentially lower costs driven by PEM fuel cell applications in vehicles. It's not clear yet if the PA fuel cell can be cost-effectively scaled down to compete in residentialsized (i.e., 2 to $10 \mathrm{~kW}$ ) applications.

\section{Proton Exchange Membrane Fuel Cell}

Until the last few years, PEM fuel cells received relatively little attention for stationary power application. PEM fuel cells have a very high energy density, which makes them particularly attractive for vehicular applications, where size and weight are prime considerations. On the other hand, the potential efficiency of the PEM fuel cell, while a significant improvement compared to internal combustion engines, is inferior to the other fuel cells described in this report. 
Like the other fuel cells, the key factor affecting the future efficacy of PEM fuel cell is its cost. Lower costs are important for the PEM fuel cell in both vehicular and stationary markets, but perhaps even more so for the latter. Compared to internal combustion engines, PEM fuel cells offer significant advantages in efficiency and emissions, so a moderate cost disadvantage will be allowed. On the other hand, lower cost may be the only significant potential advantage for the PEM fuel cell in the stationary market. The PEM fuel cell is more compact, and its lower operating temperature and solid electrolyte may result in a safer product compared to the other fuel cell options, but it's not clear if these advantages are highly valued by any stationary market niche. Thus, assuming the PEM fuel cell can demonstrate durability and reliability at least comparable to the other fuel cell options, it would appear it must compete mostly on cost.

PEM fuel cell cost targets for vehicular applications are generally around $\$ 100 / \mathrm{kW}$ (higher for buses, lower for autos). On the surface, it would appear that if these goals could be met; the PEM fuel cell would have a tremendous cost advantage over other stationary fuel cell options. The requirements for the two markets are substantially different, however. The stationary product must have a service life that is about an order of magnitude longer and must also include a DC/AC inverter. Thus, its cost will be substantially higher.

Currently, several developers have plans to field commercial PEM fuel cells for the stationary market in the next few years. Ballard is developing a $250-\mathrm{kW}$ product, presumably to compete with ONSI's PC-25 $5^{\mathrm{TM}}$, while at least five other companies are developing 2 - to $10-\mathrm{kW}$ units for residential applications. In the near-term, the Ballard unit will likely have to be priced at or below the ONSI unit to be competitive. In the long-run, lessons learned and costs shared with the vehicular application has the potential to drive the PEM fuel cell cost well below the PA fuel cell's mature potential. Unless the PA fuel cell can maintain a significant efficiency advantage, it may be driven from the market. On the other hand, the PA fuel cell has all the advantages of being first on the market and may be able to "lock out" the competition if its costs can be lowered quickly enough.

\section{Molten Carbonate Fuel Cell}

Although full-scale and nearly full-scale demonstrations of this fuel cell technology have been completed by two U.S. developers [Energy Research Corporation (ERC) and MC Power], the demonstrations achieved mixed results. Therefore, it will still be at least a few years until MC technology is commercially available. Compared to PA fuel cells, MC fuel cells offer higher efficiency and the prospect of lower costs per $\mathrm{kW}$. In fact, $\mathrm{MC}$ fuel cells offer the highest efficiency of any fuel cell operating by itself (i.e., not integrated with some form of a bottoming cycle). Complexities with balance-of-plant components (e.g., $\mathrm{CO}_{2}$ recycle stream) may limit cost-effective application to relatively large capacities (perhaps $250-\mathrm{kW}$ or larger), but this is not a foregone conclusion. ERC and MC-Power are currently planning $0.25-$ to $3-\mathrm{MW}$ and $0.5-\mathrm{MW}$ commercial units, respectively, aimed primarily at distributed utility and industrial markets. While its projected long-term efficiency is competitive with central station combined-cycle plants, its expected mature cost is not. However, it should be a strong competitor for applications requiring 0.5 - to $10-\mathrm{MW}$ capacity.

The MC fuel cell's operating temperature $\left(650^{\circ} \mathrm{C}\right)$ presents opportunities for combined-cycle power plant configurations or the production of high-temperature process steam for industrial applications. The latter would appear to offer more attraction. Although the MC fuel cell 
exhaust is warm enough to produce "utility temperature" steam, steam turbines are not very efficient or cost-effective conversion devices at sizes less than $10 \mathrm{MW}$. On the other hand, MC fuel cell exhaust is not warm enough to efficiently drive a gas turbine without supplemental firing. ERC has proposed a hybrid cycle that integrates both gas and steam turbines with a MC fuel cell. Studies completed for both 20 - and 200-MW power plants show levelized electricity costs that are competitive with, but not superior to combined-cycle plants, unless natural gas prices rise more quickly than currently projected.

Glitches at ERC's and MC-Power's demonstration plants should be overcome so that marketentry commercial products are available in the intermediate-term. Still, performance and reliability must be proven before attention can be fully focused on cost reduction. The installed cost of the MC fuel cell is predicted to be slightly higher than the PA fuel cell at initial introduction, but the former should have a significant performance advantage. Further cost reduction and performance improvement for the $\mathrm{MC}$ fuel cell is predicted in the long-term. By then, its cost and performance could be superior to a PA fuel cell, but it may face stiff competition from the SO fuel cell or a SO fuel cell/gas turbine hybrid.

\section{Solid Oxide Fuel Cell}

In the long term, SO fuel cells may become the preferred FC technology for all stationary applications. By itself, the projected cost and performance of the SO fuel cell is inferior to the MC fuel cell. However, when coupled with a gas turbine (GT) bottoming cycle, the projected SO fuel cell hybrid cost is comparable to the $\mathrm{MC}$ fuel cell, while its efficiency is superior to projected efficiencies for combined-cycle power plants as well as the MC fuel cell. Clearly, if the projected cost and performance characteristics for the SO fuel cell/GT hybrid comes to fruition, it will likely become the preferred technology for the distributed utility market and will be a strong competitor to combined-cycle power plants for central generation applications. Industrial applications might still prefer the MC fuel cell, depending on site-specific needs for process heat and the value of electric power.

Compared to the MC fuel cell, two key features of the SO fuel cell allow effective integration of a bottoming cycle. First, SO fuel cell technology is more amenable to pressurization than MC fuel cell technology, especially at pressures matching the inlet requirements of GTs. Second, the exhaust temperature from a SO fuel cell is also a good match for the inlet requirements of GTs. Finally, GTs are more effective conversion devices than steam turbines at sizes below $10 \mathrm{MW}$.

Unlike the MC and PA fuel cells, but like the PEM fuel cell, SO fuel cells are currently being considered for micro-generation applications such as portable power and individual residences. Thus, various forms of SO fuel cells may eventually see applications in all stationary markets.

SO fuel cells offer a lot of promise, but will probably not be commercially-available until at least a few years after the turn of the century. The capacity of the largest units tested to date is only $100 \mathrm{~kW}$. System tests have yet to be conducted at the operating pressures required for GT integration. Finally, the most significant problem facing SO fuel cell development may be its cost. Current SO fuel cell test units are reportedly an order of magnitude more costly than MC fuel cell and PEM fuel cell test units and roughly two orders of magnitude higher than required for cost-effective application. Concerns about costs have driven some developers towards lower 
temperature designs that operate at about $800^{\circ} \mathrm{C}$ compared to $1000^{\circ} \mathrm{C}$. Less expensive materials can be used at the lower temperature, but performance attributes tend to suffer. 


\section{DoD Fuel Cell Demonstration Program}

The FY93 Defense Appropriations Act provided $\$ 18 \mathrm{M}$ for the installation of PA fuel cells at DoD installations. This funding was supplemented by $\$ 18.75 \mathrm{M}$ in the FY94 Act ${ }^{7}$. An additional $\$ 1.25 \mathrm{M}$ was appropriated in FY94 for PA research and development. The purposes of the program are to stimulate growth in the fuel cell industry and determine the role that fuel cells should play in DoD's long-term energy supply strategy. The purpose of the R\&D funding is to accelerate research efforts focused on technological improvements that reduce fuel cell manufacturing costs.

The U.S. Army Corps of Engineers Construction Engineering Research Laboratories (CERL) was selected by the Defense Utilities Coordinating Council to coordinate the program for all three Services. CERL's responsibilities include selecting sites, developing specifications, procuring equipment and installation, monitoring system performance, and developing fuel cell application guidelines based upon program results.

ONSI was awarded two separate contracts to provide "turnkey" PA power plants at $30 \mathrm{DoD}$ locations, identified in Table 1. The procurement packages included site engineering, equipment, installation, startup, operations and maintenance training, and a 5-year maintenance contract. The contracted purchase price declined from $\$ 1.1 \mathrm{M}$ per $200-\mathrm{kW}$ unit for the first contract to $\$ 637 \mathrm{~K}$ in the second contract, which allowed more fuel cells to be purchased. Twelve fuel cells were procured under the FY93 appropriation; the majority of these were installed in 1995. The remaining 18 fuel cells were procured under the FY94 appropriation, and were installed by the end of 1997.

Site contact, application, performance, and cost data for the systems in the Fuel Cell Demonstration Program are presented in Tables 1 through 4, respectively. Per the requirements of the selection process, the sites are evenly distributed among the Services and across the U.S. Other selection criteria were energy savings, impact on local air quality, and the potential for cost sharing with the local utilities. No FORSCOM sites were selected for this program, but none formally applied.

Detailed performance data have been reported for the first set of fuel cells, with more limited information available on the second set. Performance to date has generally been good. The only significant problems to develop with the first set were a decrease in water treatment resin life and cell stack cooling loop corrosion. These problems were worst in Southwestern U.S. locations, where warmer weather reduces the amount of internal water recovery and makeup water is generally poorer in quality. Corrective actions were taken, and the fuel cells have subsequently performed well. The raw availability of units in the first set has ranged from 51 to $83 \%$.

However, when events judged by CERL to be "extraneous to immediate power plant issues" are removed, the availability of units in the first set has ranged from 89 to $99 \%$. The mean time between forced outages has been a little over 900 hours. Electric conversion efficiencies have ranged from 33 to $38 \%$, based on the LHV of the fuel, which compares to a rated value of $40 \%$, when new. Even better performance is anticipated with the units installed in 1997, which were mostly ONSI's most recent model, the PC-25C ${ }^{\mathrm{TM}}$, whereas the first set of 12 units were either $\mathrm{PC}-25 \mathrm{As}^{\mathrm{TM}}$ or Bs.

\footnotetext{
${ }^{7} \$ 1.7 \mathrm{M}$ of Army funding was subsequently withdrawn to help pay for peace-keeping actions in Somalia and Haiti.
} 
Table 1. DoD Fuel Cell Demonstration Program - Site Contact Data

\begin{tabular}{|c|c|c|c|c|}
\hline Installation Name & Department & $\begin{array}{l}\text { Installation } \\
\text { Location }\end{array}$ & Contact Name & Phone \\
\hline 911th Airlift Wing & Air Force & Pittsburgh, PA & Frank Rosa & (412) 474-8574 \\
\hline Laughlin AFB & Air Force & Del Rio, TX & Larry Eckert & (830) $298-5853$ \\
\hline Westover AFB & Air Force & Chicopee, MA & John Czuber & $(413) 557-3554$ \\
\hline Little Rock AFB & Air Force & Little Rock, AR & Bill Threet & $(501) 988-7674$ \\
\hline Davis Monthan AFB & Air Force & Tucson, $A Z$ & Steve Weleck & (520) $228-4253$ \\
\hline Edwards AFB & Air Force & Edwards, CA & Ken Munson & $(805) 277-2430$ \\
\hline Barksdale AFB & Air Force & Bossier City, LA & Nathan Cost & $(318) 456-5039$ \\
\hline 934th Air Reserve Wing & Air Force & Minneapolis, MN & $\begin{array}{c}\text { Mehrdad } \\
\text { "Dodd" Sadeghi }\end{array}$ & $(612) 713-1912$ \\
\hline Nellis AFB & Air Force & Las Vegas, NV & Gene Rogers & $(702) 652-7777$ \\
\hline Kirtland AFB & Air Force & Albuquerque, NM & $\begin{array}{c}\text { Brian } \\
\text { Dohmanen } \\
\end{array}$ & N/A \\
\hline Vandenberg AFB & Air Force & Vandenberg, CA & $\begin{array}{l}\text { Lt. Antoinette } \\
\text { Burns }\end{array}$ & $(805) 734-8232$ \\
\hline Watervliet Arsenal & Army & Albany, NY & $\begin{array}{c}\text { Paul } \\
\text { Gentiluomo }\end{array}$ & (518) $266-3860$ \\
\hline Ft. Huachuca & Army & Sierra Vista, AZ & Bill Stein & $(520) 533-1861$ \\
\hline Ft. Richardson & Army & Anchorage, AK & Jim Buckley & $(907) 428-6780$ \\
\hline Ft. Bliss & Army & El Paso, TX & Joe Mathis & $\begin{array}{c}\text { (915) } 568-3107 \\
\text { ext: } 6627\end{array}$ \\
\hline Ft. Eustis & Army & Newport News, VA & Daniel Wood & $(757) 878-3127$ \\
\hline Pine Bluff Arsenal & Army & Pine Bluff, AR & Nancy Rimmer & (501) $540-3312$ \\
\hline U.S. Military Academy & Army & West Point, NY & Bob Kronk & $(914) 938-5219$ \\
\hline $\begin{array}{l}\text { U.S. Army Soldier } \\
\text { Systems Command }\end{array}$ & Army & Natick, MA & David Duncan & $(508) 233-4934$ \\
\hline Picatinny Arsenal & Army & Dover, NJ & Hyman Izraeli & (201) 724-2492 \\
\hline Jacksonville NAS & Navy & Jacksonville, FL & Larry Frobes & (904) $777-7593$ \\
\hline Fallon NAS & Navy & Fallon, NV & $\begin{array}{c}\text { Greg } \\
\text { Westmoreland }\end{array}$ & $(702) 426-2410$ \\
\hline $\begin{array}{l}\text { John C. Stennis Space } \\
\text { Center }\end{array}$ & Navy & Space Center, MS & $\begin{array}{c}\text { Robert } \\
\text { Heitzmann } \\
\end{array}$ & $(601) 688-4062$ \\
\hline Navy Sub Base-Groton & Navy & Groton, CT & Steve Pucino & $(860) 449-4485$ \\
\hline $\begin{array}{c}\text { Naval Construction } \\
\text { Battalion Center }(C B C), \\
\text { Port Hueneme }\end{array}$ & Navy & Port Hueneme, CA & Carl Rhoads & $(805) 982-4313$ \\
\hline $\begin{array}{c}\text { Naval Education Training } \\
\text { Center }\end{array}$ & Navy & Newport, RI & John Alfano & $(401) 841-2161$ \\
\hline U.S. Naval Academy & Navy & Annapolis, MD & Chi Chiu & $(410) 293-1091$ \\
\hline Camp Pendleton MCB & Marine Corps & Oceanside, CA & Jim Beesing & (760) $725-5447$ \\
\hline Twentynine Palms MCB & Marine Corps & $\begin{array}{c}\text { Twentynine Palms, } \\
\text { CA }\end{array}$ & $\begin{array}{c}\text { Patrick } \\
\text { Dougherty }\end{array}$ & (760) 830-2395 \\
\hline $\begin{array}{c}\text { National Defense Center } \\
\text { for Environmental } \\
\text { Excellence (NDCEE) }\end{array}$ & $\overline{D o D}$ & Johnstown, PA & Mark Funyak & $(814) 269-6458$ \\
\hline
\end{tabular}


Table 2. DoD Fuel Cell Demonstration Program - Application Data

\begin{tabular}{|c|c|c|c|c|c|}
\hline Installation Name & $\begin{array}{l}\text { ONSI Fuel } \\
\text { Cell Model }\end{array}$ & $\begin{array}{l}\text { Fuel Cell } \\
\text { Application }\end{array}$ & $\begin{array}{l}\text { Thermal } \\
\text { Application }\end{array}$ & Options Purchased & Method of Connection \\
\hline 91 1th Airlift Wing & PC25C & $\begin{array}{c}\text { Central Heating } \\
\text { Plant }\end{array}$ & Space heat & $\begin{array}{l}\text { Transformer, storage tank, } \\
\text { high grade heat, } 56 \text { month } \\
\text { maintenance contract. }\end{array}$ & Grid connected. \\
\hline Laughlin AFB & PC25C & Hospital & $\begin{array}{l}\text { Space heat, } \\
\text { Reheat, } \\
\text { Domestic hot } \\
\text { water (DHW) }\end{array}$ & $\begin{array}{l}\text { 2nd low grade heat, } 56 \text { month } \\
\text { maintenance contract. }\end{array}$ & Grid connected at existing transformer. \\
\hline Westover AFB & PC25C & $\begin{array}{l}\text { Central Boiler } \\
\text { Plant }\end{array}$ & $\begin{array}{c}\text { Boiler makeup } \\
\text { water, } \\
\text { Condensate } \\
\text { return }\end{array}$ & $\begin{array}{l}\text { Transformer, high grade heat, } \\
\text { 2nd thermal loop, } 56 \text { month } \\
\text { mainteriance contract. }\end{array}$ & Grid connected at new transformer. \\
\hline Little Rock AFB & PC25C & Hospital & $\begin{array}{l}\text { Space heat, } \\
\text { Reheat }\end{array}$ & $\begin{array}{l}56 \text { month maintenance } \\
\text { contract. }\end{array}$ & Grid connected at panel. \\
\hline Davis Monthan AFB & PC25C & Gymnasium & $\begin{array}{c}\mathrm{DHW}, \text { Absorption } \\
\text { chiller }\end{array}$ & $\begin{array}{l}\text { Transformer, high grade heat, } \\
56 \text { month maintenance } \\
\text { contract. }\end{array}$ & Grid connected at new transformer. \\
\hline Edwards AFB & PC25C & Hospital & Space heat & $\begin{array}{l}\text { High grade heat, } 56 \text { month } \\
\text { maintenance contract. }\end{array}$ & Grid connected at existing transformer. \\
\hline Barksdale AFB & PC 25B & Hospital & $\begin{array}{l}\text { Space heat, } \\
\text { Reheat }\end{array}$ & $\begin{array}{l}56 \text { month maintenance } \\
\text { contract. }\end{array}$ & Grid connected at panel. \\
\hline $\begin{array}{l}\text { 934th Air Reserve } \\
\text { Wing }\end{array}$ & PC 25B & Boiler Plant & $\begin{array}{l}\text { Boiler makeup } \\
\text { water }\end{array}$ & 5 year maintenance contract. & $\begin{array}{l}\text { Grid connected at new electrical } \\
\text { transformer. }\end{array}$ \\
\hline Nellis AFB & PC 25B & $\begin{array}{l}\text { Barracks } \\
\text { Complex }\end{array}$ & $\begin{array}{l}\text { DHW, Heat } \\
\text { pump }\end{array}$ & 5 year maintenance contract. & Grid connected at main panel. \\
\hline Kirtland AFB & PC 25B & Boiler Plant & $\begin{array}{c}\text { Boiler makeup } \\
\text { water }\end{array}$ & 5 year maintenance contract. & $\begin{array}{l}\text { Grid connected at transformer. Grid } \\
\text { independent power to boiler plant. }\end{array}$ \\
\hline Vandenberg AFB & PC 25A & N/A & $\mathrm{N} / \mathrm{A}$ & 5 year maintenance contract. & \\
\hline Watervliet Arsenal & PC 25B & $\begin{array}{l}\text { Central Boiler } \\
\text { Plant }\end{array}$ & $\begin{array}{c}\text { Boiler makeup } \\
\text { water }\end{array}$ & $\begin{array}{l}56 \text { month maintenance } \\
\text { contract. }\end{array}$ & $\begin{array}{l}\text { Grid connected at existing panel. Grid } \\
\text { independent for emergency back-up. }\end{array}$ \\
\hline Ft. Huachuca & PC25C & Barracks & $\begin{array}{l}\text { Space heat, } \\
\text { DHW }\end{array}$ & $\begin{array}{l}\text { High grade heat, } 2 \text { nd thermal } \\
\text { loop, } 56 \text { month maintenance } \\
\text { contract. }\end{array}$ & $\begin{array}{l}\text { Grid connected to existing transformer } \\
\text { (no emergency back-up). }\end{array}$ \\
\hline Ft. Richardson & PC25C & Armory Building & $\begin{array}{l}\text { Space heat, } \\
\text { DHW }\end{array}$ & $\begin{array}{l}\text { Grid independent, high grade } \\
\text { heat, 2nd thermal loop, } \\
\text { Alaska differential, } 56 \text { month } \\
\text { maintenance contract. }\end{array}$ & $\begin{array}{l}\text { Grid connected to existing transformer } \\
\text { (no emergency back-up). }\end{array}$ \\
\hline
\end{tabular}


Table 2. DoD Fuel Cell Demonstration Program - Application Data (Continued)

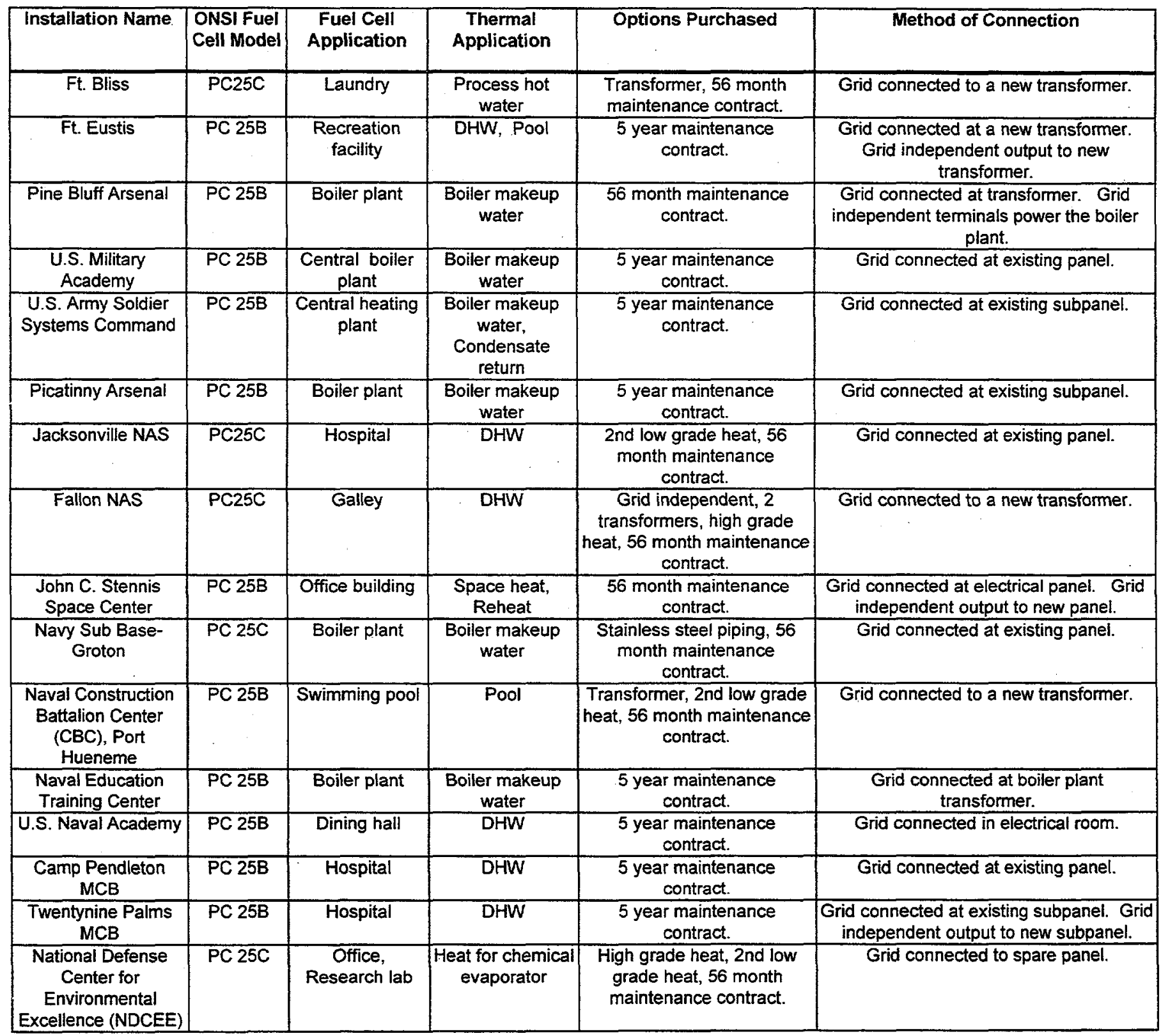


Table 3. DoD Fuel Cell Demonstration Program - Performance Data

\begin{tabular}{|c|c|c|c|c|c|c|c|}
\hline Installation Name & $\begin{array}{c}\text { Installation } \\
\text { Date }\end{array}$ & $\begin{array}{c}\text { Operating } \\
\text { Hours as } \\
\text { of } \\
9 / 30 / 1998\end{array}$ & $\begin{array}{c}\text { Cumulative } \\
\text { Electrical } \\
\text { Output as of } \\
9 / 30 / 1998 \\
\text { [MWh] }\end{array}$ & Efficiency & $\begin{array}{c}\text { Raw } \\
\text { Availability } \\
\text { as of } \\
\text { 9/30/1998 }\end{array}$ & $\begin{array}{c}\text { Cumulative } \\
\text { Thermal } \\
\text { Output as of } \\
9 / 30 / 1998 \\
\text { [MBtu] }\end{array}$ & $\begin{array}{l}\text { Waste Heat } \\
\text { Utilization \% }\end{array}$ \\
\hline 911th Airlift Wing & $12 / 18 / 96$ & 12,729 & 2365 & $N / A^{8}$ & $83 \%$ & See note 1. & est. $29 \%$ \\
\hline Laughlin AFB & $9 / 16 / 97$ & 5,980 & 1181 & N/A & $67 \%$ & See note 1. & est. $75 \%$ \\
\hline Westover AFB & $9 / 19 / 97$ & 8,191 & 1622 & N/A & $91 \%$ & See note 1. & est. $45 \%$ \\
\hline Little Rock AFB & $8 / 17 / 97$ & 7,591 & 1424 & N/A & $87 \%$ & See note 1. & est. $85 \%$ \\
\hline Davis Monthan AFB & $10 / 14 / 97$ & 5,358 & 1021 & N/A & $61 \%$ & See note 1. & est. $65 \%$ \\
\hline Edwards AFB & $7 / 5 / 97$ & 5,169 & 977 & N/A & $44 \%$ & See note 1. & est. $23 \%$ \\
\hline Barksdale AFB & $7 / 24 / 97$ & 7,730 & 1497 & N/A & $75 \%$ & See note 1. & est. $90 \%$ \\
\hline 934th Air Reserve Wing & $2 / 1 / 95$ & 23,784 & 3901 & $29 \%$ & $74 \%$ & 113 & $1 \%$ \\
\hline Nellis AFB & $9 / 23 / 95$ & 15,006 & 2627 & $30 \%$ & $56 \%$ & 5018 & $48 \%$ \\
\hline Kirtland AFB & $7 / 20 / 95$ & 13,520 & 1978 & $31 \%$ & $48 \%$ & 2412 & $25 \%$ \\
\hline Vandenberg AFB & N/A & N/A & N/A & N/A & N/A & N/A & N/A \\
\hline Watervliet Arsenal & $10 / 29 / 97$ & 7,107 & 1340 & $34 \%$ & $87 \%$ & 2890 & $58 \%$ \\
\hline Ft. Huachuca & $7 / 28 / 97$ & 5,736 & 1090 & N/A & $58 \%$ & See note 1 & est. $44 \%$ \\
\hline Ft. Richardson & $12 / 17 / 96$ & 9,011 & 1497 & N/A & $56 \%$ & See note 1. & est. $45 \%$ \\
\hline Ft. Bliss & $10 / 10 / 97$ & 6,949 & 1269 & N/A & $81 \%$ & See note 1. & est. $17 \%$ \\
\hline Ft. Eustis & $9 / 12 / 95$ & 11,455 & 2145 & $32 \%$ & $42 \%$ & 1179 & $15 \%$ \\
\hline Pine Bluff Arsenal & $10 / 21 / 97$ & 6,144 & 1160 & $35 \%$ & $73 \%$ & 3086 & $72 \%$ \\
\hline U.S. Military Academy & $11 / 17 / 95$ & 19,629 & 3607 & $32 \%$ & $77 \%$ & 15,122 & $100 \%$ \\
\hline $\begin{array}{l}\text { U.S. Army Soldier } \\
\text { Systems Center }\end{array}$ & $1 / 27 / 95$ & 26,566 & 4493 & $32 \%$ & $81 \%$ & 1426 & $8 \%$ \\
\hline Picatinny Arsenal & $10 / 11 / 95$ & 18,723 & 3588 & $32 \%$ & $71 \%$ & 15,551 & $100 \%$ \\
\hline Jacksonville NAS & $3 / 18 / 97$ & 10,239 & 1871 & N/A & $77 \%$ & See note 1. & est. $56 \%$ \\
\hline Fallon NAS & $3 / 30 / 97$ & 9,654 & 1652 & N/A & $69 \%$ & See note 1. & est. $10 \%$ \\
\hline $\begin{array}{l}\text { Naval Oceanographic } \\
\text { Office }\end{array}$ & $10 / 7 / 97$ & 7,522 & 1430 & $36 \%$ & $84 \%$ & 1464 & $28 \%$ \\
\hline $\begin{array}{l}\text { Navy Sub Base-New } \\
\text { London }\end{array}$ & $9 / 30 / 97$ & 8,131 & 1609 & N/A & $93 \%$ & See note 1 & est. $90 \%$ \\
\hline CBC, Port Hueneme & $8 / 17 / 97$ & 6,711 & 1323 & $37 \%$ & $69 \%$ & 2054 & $44 \%$ \\
\hline Newport NAS & $1 / 23 / 95$ & 27,008 & 4319 & $30 \%$ & $82 \%$ & 6581 & $35 \%$ \\
\hline U.S. Naval Academy & $9 / 22 / 97$ & 6,872 & 970 & N/A & $78 \%$ & See note 1. & est. $78 \%$ \\
\hline Camp Pendleton MCB & $10 / 6 / 95$ & 15,762 & 2866 & $33 \%$ & $60 \%$ & 4629 & $42 \%$ \\
\hline Twentynine Palms MCB & $6 / 20 / 95$ & 16,262 & 2822 & $32 \%$ & $56 \%$ & 873 & $8 \%$ \\
\hline $\begin{array}{l}\text { National Defense Center } \\
\text { for Environmental } \\
\text { Excellence (NDCEE) }\end{array}$ & $8 / 14 / 97$ & 7,261 & 887 & N/A & $71 \%$ & See note 1 & est. $19 \%$ \\
\hline
\end{tabular}

${ }^{8}$ Not available. 
Table 4. DoD Fuel Cell Demonstration Program - Cost Data

\begin{tabular}{|c|c|c|c|c|c|c|}
\hline Installation Name & $\begin{array}{c}\text { Purchase } \\
\text { Price }\end{array}$ & $\begin{array}{l}\text { Complete } \\
\text { Cost }\end{array}$ & $\begin{array}{l}\text { Site Gas } \\
\text { Costs } \\
\text { [\$/MBtu] }\end{array}$ & $\begin{array}{c}\text { Site Electricity } \\
\text { Energy Charges: } \\
\text { (on-peak, } \\
\text { Summer Winter) } \\
\text { [\$/kWh] }\end{array}$ & \begin{tabular}{|c|} 
Site Electricity \\
Demand Charges \\
(Summer/Winter) \\
{$[\$ / \mathrm{kW}]$}
\end{tabular} & $\begin{array}{l}\text { Estimated } \\
\text { Annual } \\
\text { Savings } \\
\text { (net) }\end{array}$ \\
\hline 911th Airlift Wing & $\$ 636,525$ & $\$ 969,856$ & $\mathrm{~N} / \mathrm{A}$ & N/A & N/A & $\$ 44,000$ \\
\hline Laughlin AFB & $\$ 636,525$ & $\$ 920,123$ & N/A & N/A & $\overline{N / A}$ & $\$ 42,000$ \\
\hline Westover AFB & $\$ 636,525$ & $\$ 966,381$ & N/A & N/A & N/A & $\$ 54,000$ \\
\hline Little Rock AFB & $\$ 636,525$ & $\$ 895,448$ & N/A & N/A & $\mathrm{N} / \mathrm{A}$ & $\$ 90,000$ \\
\hline Davis Monthan AFB & $\$ 636,525$ & $\$ 1,041,184$ & N/A & N/A & $\mathrm{N} / \mathrm{A}$ & $\$ 61,000$ \\
\hline Edwards AFB & $\$ 636,525$ & $\$ 908,216$ & N/A & N/A & $\overline{N / A}$ & $\$ 96,000$ \\
\hline Barksdale AFB & $\$ 636,525$ & $\$ 895,448$ & N/A & N/A & N/A & $\$ 40,000$ \\
\hline 934th Air Reserve Wing & $\$ 1,100,000$ & $\$ 1,300,000$ & $\$ 2.61$ & 0.024 & $9.25 / 6.61$ & $\$ 33,000$ \\
\hline Nellis AFB & $\$ 1,100,000$ & $\$ 1,300,000$ & $\$ 2.45$ & $0.066 / 0.041$ & 7.90 & $\$ 38,000$ \\
\hline Kirtland AFB & $\$ 1,100,000$ & $\$ 1,300,000$ & $\$ 3.09$ & $0.069 / 0.055$ & 8.70 & $\$ 59,000$ \\
\hline Vandenberg AFB & $\$ 1,100,000$ & $\$ 1,300,000$ & N/A & N/A & N/A & $\$ 32,000$ \\
\hline Watervliet Arsenal & $\$ 636,525$ & $\$ 895,448$ & N/A & N/A & N/A & $\$ 76,000$ \\
\hline Ft. Huachuca & $\$ 636,525$ & $\$ 933,413$ & N/A & N/A & N/A & $\$ 67,000$ \\
\hline Ft. Richardson & $\$ 636,525$ & $\$ 1,003,291$ & N/A & N/A & N/A & $\$ 67,000$ \\
\hline Ft. Bliss & $\$ 636,525$ & $\$ 928,416$ & N/A & N/A & N/A & $\$ 59,000$ \\
\hline Ft. Eustis & $\$ 1,100,000$ & $\$ 1,300,000$ & $\$ 2.72$ & 0.0198 & 12.62 & $\$ 41,000$ \\
\hline Pine Bluff Arsenal & $\$ 636,525$ & $\$ 895,448$ & N/A & N/A & N/A & $\$ 63,000$ \\
\hline U.S. Military Academy & $\$ 1,100,000$ & $\$ 1,300,000$ & $\$ 5.06$ & 0.0531 & $11.96 / 8.44$ & $\$ 30,000$ \\
\hline $\begin{array}{l}\text { U.S. Army Soldier } \\
\text { Systems Command }\end{array}$ & $\$ 1,100,000$ & $\$ 1,300,000$ & $\$ 5.23$ & $0.071 / 0.08$ & $16.11 / 9.83$ & $\$ 53,000$ \\
\hline Picatinny Arsenal & $\$ 1,100,000$ & $\$ 1,300,000$ & $\$ 3.50$ & 0.07 & $9.22 / 8.31$ & $\$ 94,000$ \\
\hline Jacksonville NAS & $\$ 636,525$ & $\$ 920,123$ & N/A & N/A & $\bar{N} / A$ & $\$ 90,000$ \\
\hline Fallon NAS & $\$ 636,525$ & $\$ 1,007,827$ & N/A & N/A & N/A & $\$ 58,000$ \\
\hline $\begin{array}{c}\text { John C. Stennis Space } \\
\text { Center } \\
\end{array}$ & $\$ 636,525$ & $\$ 895,448$ & N/A & N/A & N/A & $\$ 39,000$ \\
\hline Navy Sub Base-Groton & $\$ 636,525$ & $\$ 908,544$ & N/A & N/A & N/A & $\$ 98,000$ \\
\hline $\begin{array}{c}\text { Naval Construction } \\
\text { Battalion Center (CBC) } \\
\text { Port Hueneme }\end{array}$ & $\$ 636,525$ & $\$ 953,091$ & N/A & N/A & N/A & $\$ 73,000$ \\
\hline $\begin{array}{c}\text { Naval Education Training } \\
\text { Center }\end{array}$ & $\$ 1,100,000$ & $\$ 1,300,000$ & $\$ 4.25$ & 0.045 & 13.26 & $\$ 94,000$ \\
\hline U.S. Naval Academy & $\$ 1,100,000$ & $\$ 1,300,000$ & $\mathrm{~N} / \mathrm{A}$ & N/A & N/A & $\$ 25,000$ \\
\hline Camp Pendleton MCB & $\$ 1,100,000$ & $\$ 1,300,000$ & $\$ 3.15$ & 0.08 & N/A & $\$ 97,000$ \\
\hline Twentynine Palms MCB & $\$ 1,100,000$ & $\$ 1,300,000$ & $\$ 5.43$ & $0.138 / 0.043$ & $18.90 / 3.15$ & $\$ 57,000$ \\
\hline $\begin{array}{c}\text { National Defense Center } \\
\text { for Environmental } \\
\text { Excellence (NDCEE) }\end{array}$ & $\$ 636,525$ & $\$ 932,891$ & N/A & N/A & N/A & $\$ 15,000$ \\
\hline
\end{tabular}




\section{FORSCOM Fuel Cell Cost-Effectiveness}

Cost and performance characteristics presented in Appendix A for phosphoric acid fuel cells were combined with the economic assumptions listed in Table 5 to generate the costeffectiveness curves shown in Figures 10 and 11 . Figure 10 presents results based on current PA fuel cell characteristics, while Figure 11 is based on the projected long-term characteristics of PA fuel cells. The economic assumptions assume Federal ownership and use the fuel cost escalation rates and discount rates prepared for the Federal Energy Management Program (FEMP) by the National Institute of Standards and Technology.

Economic effectiveness is presented as a function of current electricity and natural gas (or propane, in the case of Ft. Irwin) costs, and the percent of fuel cell waste heat (thermal utilization or TU) utilized to displace natural gas otherwise fired in a boiler or water heater. Sites with electricity and natural gas cost combinations to the right of the TU lines are cost-effective, while those to the left are not. Thus, with current PA technology, Ft. Drum and Ft. Irwin would be cost-effective if applications could be identified that utilized approximately $40 \%$ and $60 \%$, respectively, of the cogenerated thermal energy. With the cost reductions and performance improvements expected in the long-term, PA fuel cells are projected to be cost-effective at Ft. Bragg and Ft. Polk, as well as at Ft. Drum and Ft. Irwin. PA fuel cells are not cost-effective at the nine remaining major FORSCOM installations based on current projections of PA fuel cell technology characteristics and fuel costs. The improvement in cost-effectiveness from the current to long-term scenario is not as great as might be expected by the cost reductions and performance improvements documented in Appendix A. This outcome can be attributed to a $\$ 1000 / \mathrm{kW}$ rebate that has been available for PA fuel cells for the last few years and was included in the calculations of current cost-effectiveness, but not long-term cost-effectiveness.

Table 5. Economic Assumptions for Cost-Effectiveness Calculations 9

$\begin{array}{ll}\text { Discount rate } & 6.9 \% \\ \text { General inflation rate } & 3.0 \% \\ \text { Electricity escalation rate } & 2.43 \% \\ \text { Natural gas escalation rate } & 2.75 \% \\ \text { Property tax rate } & 0 \% \\ \text { Income tax rate } & 0 \% \\ \text { Price year for estimates } & 1997 \\ \text { Construction year } & 1998 \\ \text { First year of operation } & 1999 \\ \text { Last year of operation } & 2018\end{array}$

\footnotetext{
${ }_{9}^{9}$ Discount rate, general inflation rate, and fuel price escalation rates based on data presented in Energy Price Indices and Discount Factors for Life-Cycle Cost Analysis - April 1997, prepared by the National Institute of Standards and Technology for the Federal Energy Management Program
} 


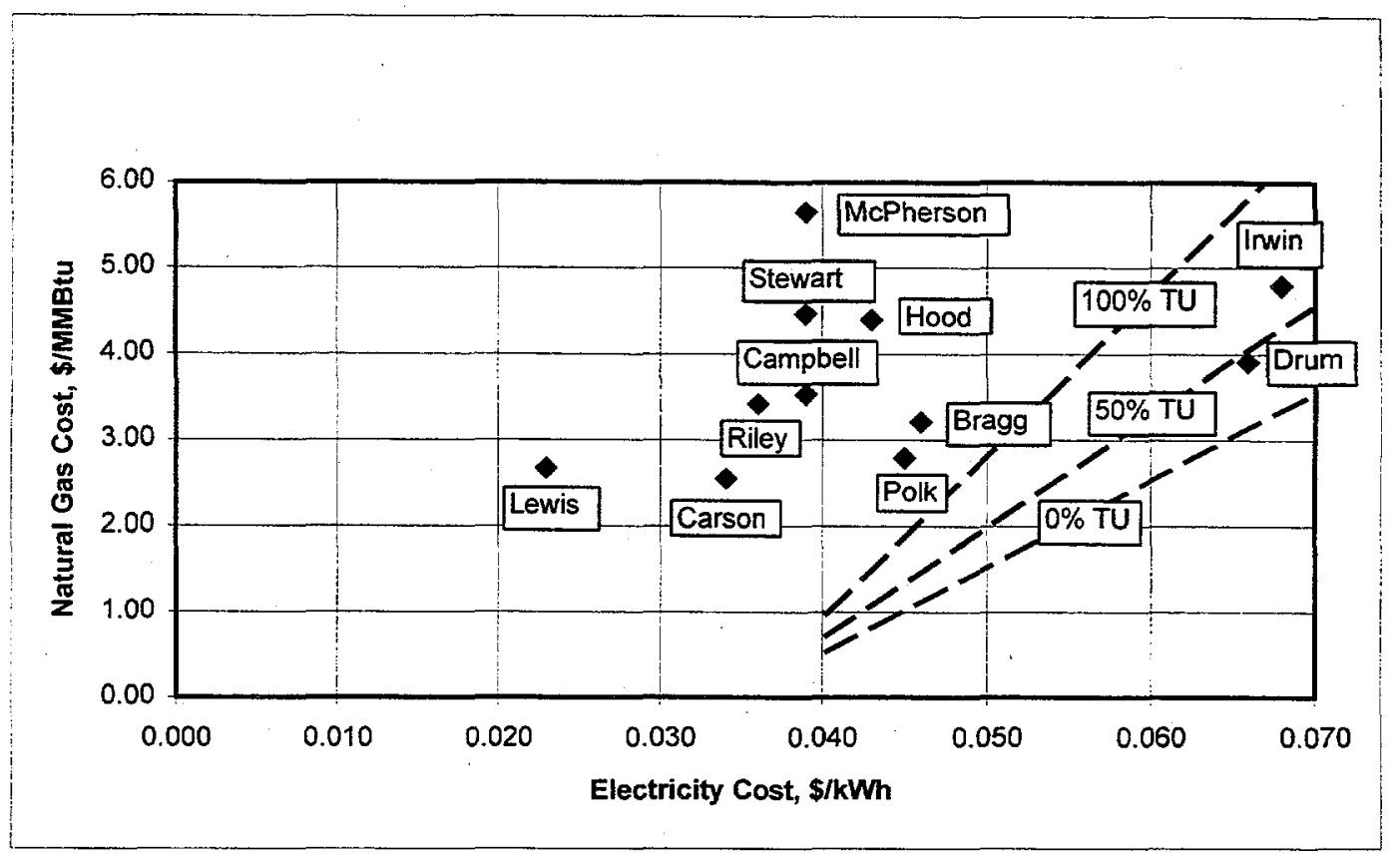

Figure 10. Current Cost-Effectiveness

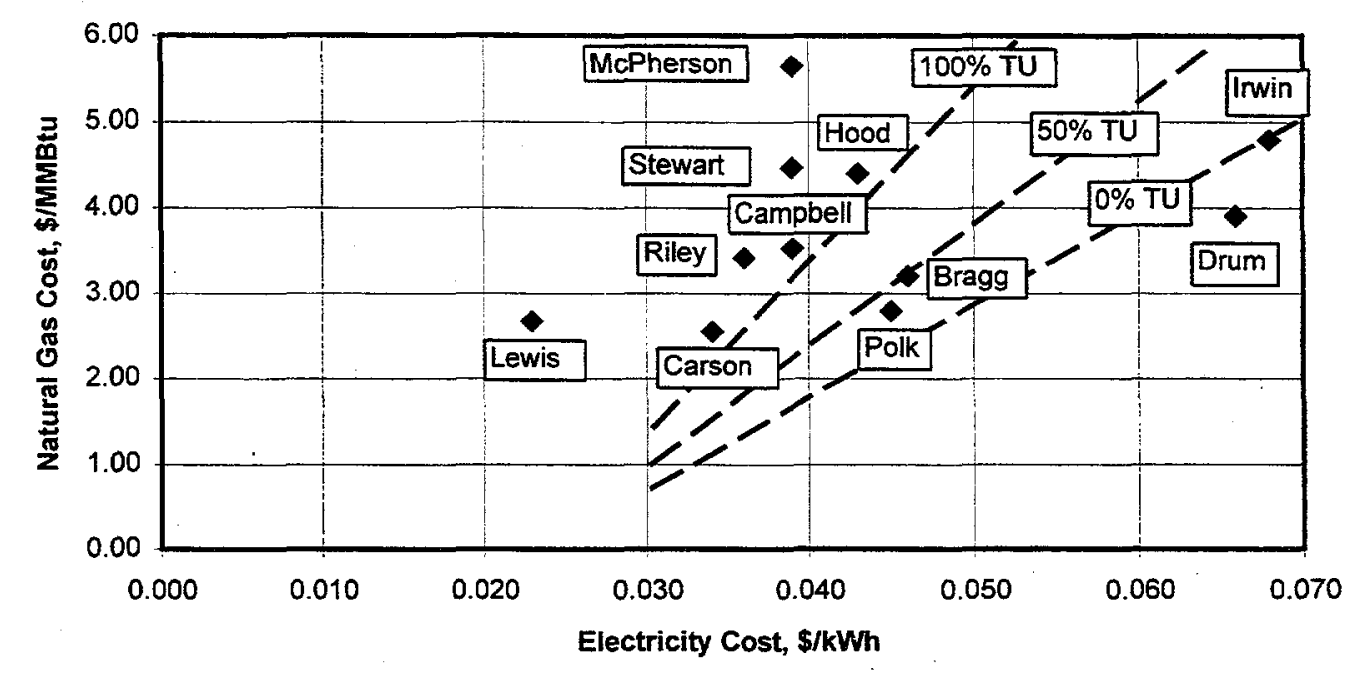

Figure 11. Long-Term Cost-Effectiveness 
Two points regarding the economic assumptions should be emphasized. First, the economic analysis assumes government ownership. While energy service companies (ESCOs) could be hired to provide fuel cell services (e.g., the fuel cell ESCO could own and operate a fuel cell and sell the electricity and thermal energy to the installation), their service will need to incorporate higher discount rates and shorter capital recovery periods that will make fuel cell economics less attractive than shown in Figures 10 or 11 . This scenario was recently realized at Ft. Drum, where the prospective fuel cell ESCO was unable to offer a proposal that was economically attractive to both parties, even though the prospective applications looked attractive when evaluated from a government ownership perspective. Of course, ESCOs do provide several valuable services, including access to capital that may be difficult for installations to obtain and the responsibility for equipment operation and maintenance. Hiring an ESCO to own and operate a fuel cell may still be more attractive for some installations, but it will result in higher capital-related costs.

The second point concerns the future costs of electricity and natural gas. The latest projections prepared for FEMP predict that electricity and natural gas prices will rise at a rate less than general inflation, i.e., prices will decline in "real" terms. This forecast contrasts sharply with predictions made in the previous year and for the last 25 years or so. While these predictions, if they come true, would be good news for energy consumers, the impact of these assumptions (in particular, the projected real reductions in electricity prices) on fuel cells is a general reduction in cost-effectiveness.

The cost of grid-supplied electric power is the most important site-specific factor affecting fuel cell cost-effectiveness. The cost of fuel and the utilization of waste heat are important, but secondary factors. Deregulation of retail electricity in the next few years will likely reduce the cost of electricity for most electricity users, including FORSCOM. For example, Ft. Drum recently signed an agreement with its electric utility that should reduce its average cost of electricity by about $25 \%$. At a minimum, the prospect of deregulation has created greater uncertainty for future electricity costs, hence greater uncertainty regarding the benefit of any self-generating concept, including fuel cells. Therefore, FORSCOM energy managers should probably wait until the impact of electricity deregulation is clearer before seriously considering fuel cells as an energy supply option. Exceptions to this general rule would be applications requiring premium power quality or reliability, or reduced emissions. FORSCOM should also take advantage of any extension in the DoD Fuel Cell Demonstration Program, although there are no plans for an extension at this time. Otherwise, continued monitoring of the progress of fuel cell technology and electricity deregulation would be wise. 
Appendix A

Cost and Performance Data 


\section{Appendix A \\ Cost and Performance Data}

Tables A1 through A5 present current (1998) and long-term (in 7 to 10 years) cost and performance estimates for phosphoric acid (PA), molten carbonate (MC), solid oxide (SO), and proton exchange membrane [PEM; also known as solid polymer electrolyte (SPE)] fuel cells. These data were developed based on information gathered by reviewing published literature and communicating with fuel cell industry representatives, with supplemental assumptions by PNNL.

PA is the only fuel cell that is currently commercially available, and is only available from one manufacturer, ONSI. With over 6 years of experience with their $200-\mathrm{kW} \mathrm{PC}-25^{\mathrm{TM}}$ model, the current cost and performance characteristics of this fuel cell are reasonably well defined. In contrast to the current (1998) PA fuel cell characterization, long-term characterizations of all fuel cell technologies (including the $P A$ fuel cell) are speculative, to one degree or another. Where multiple, varying estimates were found in the data collection process, uncertainty has been addressed by specifying "low" and "high", as well as "most likely" values. Where no estimates were found in the data collection process, assumptions were made to derive a single "most likely" value for each characteristic; further development of "low" and "high" values was considered too speculative. Except for the PA fuel cell, no data were found on prospective fuel cell economies-of-scale. Rather than speculate on this factor, cost and other fuel cell characteristics are reported for specific fuel cell sizes currently being considered by fuel cell developers/manufacturers, where such data were available. 


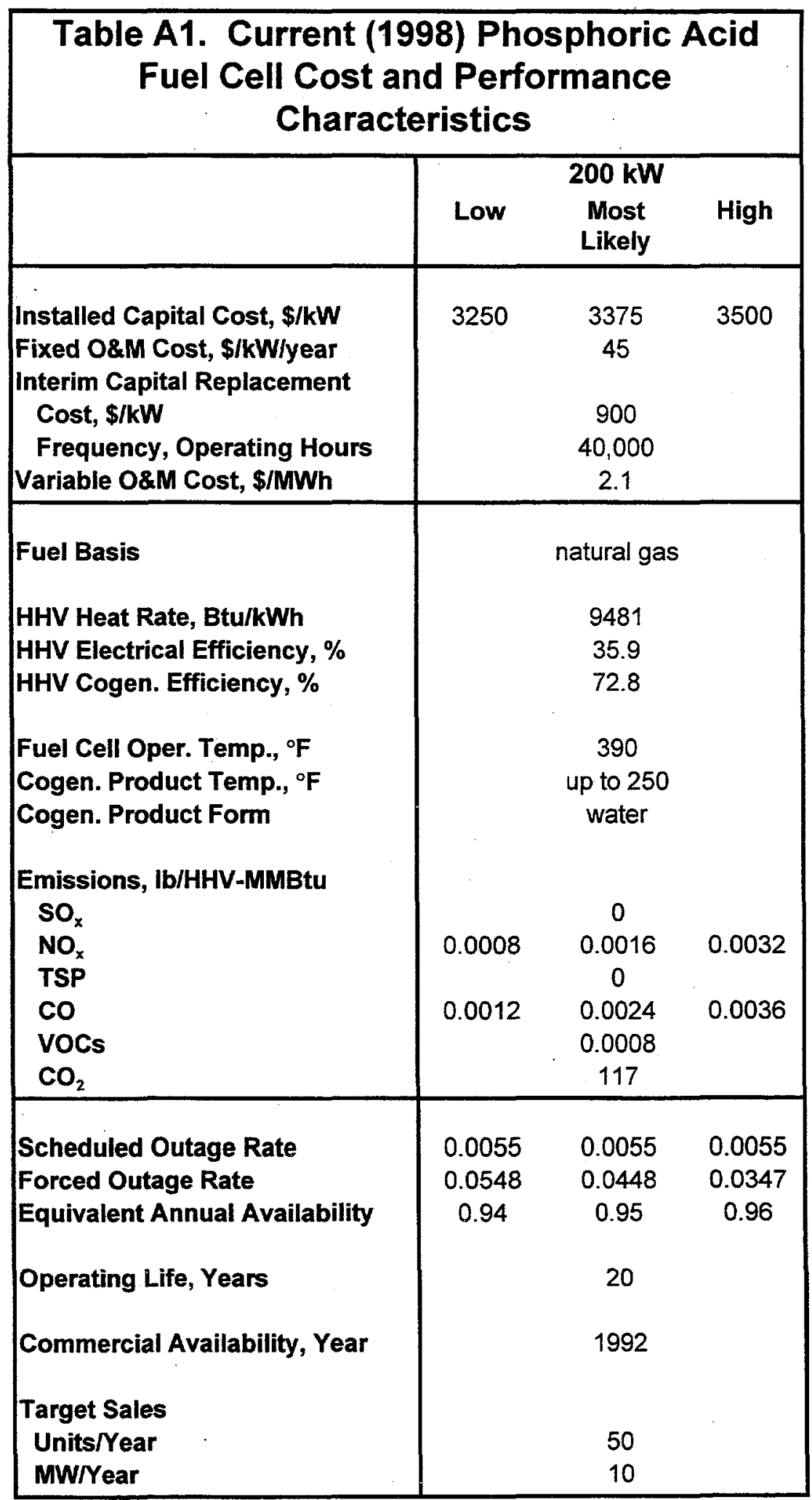




\begin{tabular}{|l|cc|}
\hline \multicolumn{3}{|c|}{$\begin{array}{c}\text { Table A2. Long-Term (7 to 10 years) } \\
\text { Phosphoric Acid Fuel Cell Cost and } \\
\text { Performance }\end{array}$} \\
\multicolumn{3}{|c|}{ Characteristics } \\
\hline \multicolumn{3}{|c|}{ Low kW } \\
\multicolumn{3}{|c|}{ Most } \\
Likely
\end{tabular}




\begin{tabular}{|c|c|c|c|}
\hline \multicolumn{4}{|c|}{$\begin{array}{l}\text { Table A3. Long-Term (7 to } 10 \text { years) } \\
\text { Proton Exchange Membrane Fuel Cell } \\
\text { Cost and Performance Characteristics }\end{array}$} \\
\hline & \multicolumn{3}{|c|}{$250 \mathrm{~kW}$} \\
\hline & Low & Most Likely & High \\
\hline Installed Capital Cost, \$/kW & 1150 & 1300 & 1600 \\
\hline Fixed O\&M Cost, \$/kW/year & & 30 & \\
\hline Cost, $\$ / \mathrm{kW}$ & 192 & 217 & 267 \\
\hline Frequency, Operating Hours & & 40,000 & \\
\hline Variable O\&M Cost, \$/MWh & & 1.4 & . \\
\hline Fuel Basis & \multicolumn{3}{|c|}{ natural gas } \\
\hline HHV Heat Rate, Btu/kWh & \multicolumn{3}{|c|}{9481} \\
\hline HHV Electrical Efficiency, \% & \multicolumn{3}{|c|}{35.9} \\
\hline HHV Cogen. Efficiency, \% & \multicolumn{3}{|c|}{70.2} \\
\hline Fuel Cell Oper. Temp., 'F & \multirow{2}{*}{\multicolumn{3}{|c|}{$\begin{array}{l}190 \\
\text { up to } 160 \\
\text { water }\end{array}$}} \\
\hline $\begin{array}{l}\text { Cogen. Product Temp., }{ }^{\circ} \mathrm{F} \\
\text { Cogen. Product Form }\end{array}$ & & & \\
\hline Emissions, lb/HHV-MMBtu & \\
\hline $\mathrm{SO}_{\mathrm{x}}$ & \\
\hline $\mathbf{N O}_{\mathbf{x}}$ & \multicolumn{3}{|c|}{0.0024} \\
\hline TSP & \multicolumn{3}{|c|}{0} \\
\hline $\mathrm{CO}$ & \multicolumn{3}{|c|}{0.0012} \\
\hline Vocs & \multicolumn{3}{|c|}{0.0008} \\
\hline $\mathrm{CO}_{2}$ & \multicolumn{3}{|c|}{117} \\
\hline Scheduled Outage Rate & \multicolumn{3}{|c|}{0.0055} \\
\hline Forced Outage Rate & \multicolumn{3}{|c|}{0.0347} \\
\hline Equivalent Annual Availability & \multicolumn{3}{|c|}{0.96} \\
\hline Operating Life, Years & \multicolumn{3}{|c|}{25} \\
\hline Commercial Availability, Year & 2000 & 2001 & 2002 \\
\hline Target Sales & \multirow{2}{*}{\multicolumn{3}{|c|}{500}} \\
\hline Units/Year & & & \\
\hline MW/Year & \multicolumn{3}{|c|}{125} \\
\hline
\end{tabular}




\begin{tabular}{|c|c|c|c|}
\hline \multicolumn{4}{|c|}{$\begin{array}{c}\text { Table A4. Long-Term (7 to } 10 \text { years) Molten } \\
\text { Carbonate Fuel Cell Cost and Performance } \\
\text { Characteristics }\end{array}$} \\
\hline & & $2.85 \mathrm{MW}$ & \\
\hline & Low & Most Likely & High \\
\hline $\begin{array}{l}\text { Installed Capital Cost, } \$ / k W \\
\text { Fixed O\&M Cost, \$/kW/year } \\
\text { Interim Capital Replacement } \\
\text { Cost, } \$ / k W \\
\text { Frequency, Operating Hours } \\
\text { Variable O\&M Cost, } \$ / M W h\end{array}$ & $\begin{array}{c}1200 \\
6 \\
400 \\
1.4\end{array}$ & $\begin{array}{c}1300 \\
8 \\
\\
430 \\
50,000 \\
2\end{array}$ & $\begin{array}{c}1500 \\
11 \\
500 \\
2.6\end{array}$ \\
\hline $\begin{array}{l}\text { Fuel Basis } \\
\text { HHV Heat Rate, Btu/kWh } \\
\text { HHV Electrical Efficiency, \% } \\
\text { HHV Cogen. Efficiency, \% } \\
\text { Fuel Cell Oper. Temp., }{ }^{\circ} \text { F } \\
\text { Cogen. Product Temp., }{ }^{\circ} \text { F } \\
\text { Cogen. Product Form } \\
\text { Emissions, Ib/HHV-MMBtu } \\
\text { SO }_{x} \\
\mathrm{NO}_{\mathrm{x}} \\
\mathrm{TSP}^{\mathrm{CO}} \\
\mathrm{CO} \\
\mathrm{VOCs} \\
\mathrm{CO}_{2}\end{array}$ & $\begin{array}{l}6300 \\
54.2\end{array}$ & $\begin{array}{c}\text { natural gas } \\
6550 \\
52.1 \\
\text { up to } 82 \\
1200 \\
\text { up to } 1050 \\
\text { steam/water }\end{array}$ & $\begin{array}{l}6800 \\
50.2\end{array}$ \\
\hline $\begin{array}{l}\text { Scheduled Outage Rate } \\
\text { Forced Outage Rate } \\
\text { Equivalent Annual Availability } \\
\text { Operating Life, Years } \\
\text { Commercial Availability, Year } \\
\text { Target Sales } \\
\text { Units/Year } \\
\text { MWYear }\end{array}$ & $\begin{array}{c}0.0192 \\
0.0416 \\
0.94\end{array}$ & $\begin{array}{c}0.0192 \\
0.0314 \\
0.95 \\
25 \\
2000\end{array}$ & $\begin{array}{c}0.0192 \\
0.0212 \\
0.96\end{array}$ \\
\hline
\end{tabular}




\begin{tabular}{|c|c|c|c|c|c|c|}
\hline \multicolumn{7}{|c|}{$\begin{array}{c}\text { Table A5. Long-Term (7 to } 10 \text { years) Solid Oxide Fuel Cell Cost and } \\
\text { Performance Characteristics }\end{array}$} \\
\hline & \multicolumn{3}{|c|}{1.9 MW Fuel Cell Only } & \multicolumn{3}{|c|}{$\begin{array}{c}5 \text { MW Fuel Cell/Gas Turbine } \\
\text { Hybrid }\end{array}$} \\
\hline & Low & Most Likely & High & Low & Most Likely & High \\
\hline $\begin{array}{l}\text { Installed Capital Cost, \$/kW } \\
\text { Fixed O\&M Cost, \$/kW/year } \\
\text { Interim Capital Replacement } \\
\text { Cost, \$/kW } \\
\text { Frequency, Operating Hours } \\
\text { Variable O\&M Cost, \$/MWh }\end{array}$ & $\begin{array}{l}1200 \\
480\end{array}$ & $\begin{array}{l}1500 \\
20 \\
\\
600 \\
40,000 \\
2.5\end{array}$ & 1700 & $\begin{array}{l}1000 \\
320\end{array}$ & $\begin{array}{c}1300 \\
20 \\
\\
400 \\
40,000 \\
2.5\end{array}$ & $\begin{array}{l}1500 \\
450\end{array}$ \\
\hline $\begin{array}{l}\text { Fuel Basis } \\
\text { HHV Heat Rate, Btu/kWh } \\
\text { HHV Electrical Efficiency, \% } \\
\text { HHV Cogen. Efficiency, \% } \\
\text { Fuel Cell Oper. Temp., }{ }^{\circ} \mathrm{F} \\
\text { Cogen. Product Temp., }{ }^{\circ} \mathrm{F} \\
\text { Cogen. Product Form } \\
\\
\text { Emissions, Ib/HHV-MMBtu } \\
\mathrm{SO}_{\mathrm{x}} \\
\mathrm{NO}_{\mathrm{x}} \\
\mathrm{TSP}^{\mathrm{CO}} \\
\mathrm{CO}^{\text {VOCs }} \\
\mathrm{CO}_{2}\end{array}$ & $\begin{array}{l}6900 \\
49.5\end{array}$ & $\begin{array}{c}\text { natural gas } \\
7250 \\
47.1 \\
\text { up to } 85 \\
1830 \\
\text { up to } 1500 \\
\text { gas/steam/ } \\
\text { water } \\
\\
\\
0 \\
0.001 \\
0 \\
0 \\
0 \\
117\end{array}$ & $\begin{array}{l}7600 \\
44.9\end{array}$ & $\begin{array}{l}5300 \\
64.4\end{array}$ & $\begin{array}{c}\text { natural gas } \\
5400 \\
63.2 \\
\text { up to } 77 \\
1830 \\
\text { up to } 400 \\
\text { steam/water }\end{array}$ & $\begin{array}{l}5500 \\
62.1\end{array}$ \\
\hline $\begin{array}{l}\text { Scheduled Outage Rate } \\
\text { Forced Outage Rate } \\
\text { Equivalent Annual Availability } \\
\text { Operating Life, Years } \\
\text { Commercial Availability, Year } \\
\text { Target Sales } \\
\text { Units/Year } \\
\text { MWYYear }\end{array}$ & 2001 & $\begin{array}{c}0.0192 \\
0.0518 \\
0.93 \\
20 \\
\\
2003 \\
\\
40 \\
76\end{array}$ & 2005 & 2001 & $\begin{array}{c}0.03846 \\
0.10352 \\
0.86 \\
20 \\
2003 \\
\\
20 \\
100\end{array}$ & 2005 \\
\hline
\end{tabular}


Appendix B

Glossary 


\section{Appendix B \\ Glossary}

Anode The electrode where fuel is electrochemically oxidized.

Bipolar Plate The combination of a separator and two current collectors. Each bipolar plate serves one-half of two adjacent cells in a stack.

Cathode The electrode where oxidant is electrochemically reduced.

Cell The repetitive unit within a fuel cell stack that consists of an anode, cathode, electrolyte, current collector, and a separator.

Current Collector A component of a cell that conducts electrons from the anode to the separator and onto the cathode.

Electrode A conductive material that provides a site for either the oxidation or reduction reaction within a cell and a barrier separating fuel or oxidant gases from the electrolyte.

Electrolyte The ionic conducting medium between the anode and the cathode within each cell.

Fuel Cell A device that directly (electrochemically) converts the chemical energy of a fuel into electrical energy from externally supplied fuel and oxidant.

Fuel Processor A device for converting raw fuel (e.g., natural gas) into fuel (e.g., hydrogen) that can be utilized by the fuel cell stack.

Inverter A device for converting the DC output of the fuel cell stack into AC power.

Membrane Electrode Assembly The anode/electrolyte/cathode "sandwich" in a PEM fuel cell.

Power Conditioner See inverter.

Separator The component that physically separates the fuel from one cell from the oxidant of the adjacent cell. Each separator serves one-half of two adjacent cells.

Stack Multiple cells connected electrically and physically in series, forming an integrated unit 


\section{Distribution}

No. of

Copies

OFFSITE

Fred Cavedo

Directorate of Public Works

1117 Frank Cochrane Drive

Suite 101

Fort Stewart, GA 31314-4940

George Dib

XVIII Airborne Corps

B3-1631

Attn: AFZA-PW-M

Fort Bragg, NC 28307-5000

$6 \quad$ Adrian Gillespie

U.S. Army Forces Command HQ

1777 Hardee Avenue SW

Fort McPherson, GA 30330-1062

Gordon Greene

Public Works

O\&M Division

85 First Street West

Fort Drum, NY 13602-5097

Rudolph Jones

11005 SW 16th Drive

Portland, OR 97219

Naresh Kapur

U.S. Army Forces Command HQ

1777 Hardee Avenue SW

Fort McPherson, GA 30330-1062

Dennis Koniecki

Directorate of Installation Support 1959 Walker Avenue

Fort McPherson, GA 30330-1018
No. of

Copies

Don Laurent

HQ JRTC

Attn: AFZX-PW-EP

2263 Louisiana Avenue

Fort Polk, LA 71459-5000

Bobby Lynn

Energy Management

U.S. Army HQ III Corps

Attn: FZF-DE-ENV

Fort Hood, TX 76544-5057

Steve Pientka

Directorate of Public Works

Energy Branch

Attn: AFZN-PW-EE

Building 408

Pershing Court

Fort Riley, KS 66442-6016

Rene Quinones

Directorate of Public Works

Energy Management

Attn: AFZJ-PW-P

Fort Irwin, CA 92310-5097

Stephen Snyder

Directorate of Environmental

Compliance

\& Management

801 Tevis Street

Fort Carson, CO 80913-4000

Bobby Starling

USA Engineering \& Support Center

Attn: CEHNC-PM-CR

PO Box 1600

Huntsville, AL 35807-4391 
No. of

Copies

Jim Thayer

Public Works

Attn: AFZH-PWP MS17

Fort Lewis, WA 98433-5000

Don Turner

U.S. Army Forces Command HQ

1777 Hardee Avenue SW

Fort McPherson, GA 30330-1062

Arlin Wright

HQ 101 st Airborne Division

Attn: AFZB-DPW-R-M

Building 865

$16^{\text {th }}$ and Ohio Street

Fort Campbell, KY 42223-5000
No. of

Copies

ONSITE

20 Pacific Northwest National Laboratory

10 DR Brown, K8-07

DR Conover, BWO

DR Dixon, K8-17

SA Parker, K5-08

7 Information Release Office 